\title{
Die werk van die Heilige Gees in die opbou van die kerk volgens Handelinge
}

Dr. A. G. S. Venter

\section{INLEIDING}

Hierdie artikel bied 'n weergawe van die bevindinge van die proefskrif met die onderwerp soos hierbo geformuleer. Die bedoeling is nie om 'n volledige opsomming van alle gegewens te bied nie. Die wyse van aanbieding is eerder om die bevindings van die studie aan te dui en enkele fasette in diepte te beredeneer.

Hierdie beredenering van die gegewens geskied eweneens in die besef dat die volledige eksegese en gepaardgaande bronverwysings in die proefskrif gebied word. Slegs enkele dieptesnitte sal dus gedoen word ten opsigte van wat as kerngedeeltes beskou word.

Die onderwerp word onder die volgende hoofde behandel:

1. Probleemstelling.

2. Oorsig oor die inhoud.

3. Bevindings en enkele dieptesnitte.

4. Slotsom en terreine vir verdere ondersoek.

\section{PROBLEEMSTELLING}

Hierdie studie moet in samehang met die referent se Th.M-studie gehanteer word ten opsigte van die skrywer, die historisiteit, die tyd van ontstaan, die doel en die struktuur van Handelinge (1980 : 7 - 29). Hierdie sake is nie in die Th.D-studie weer afsonderlik behandel nie. Waar dit nodig geag is, is wel daarna verwys en soms in besonderhede uitgespel. Indien hierdie verband met die vorige studie nie in ag geneem word nie, mag die indruk bestaan dat nie met die huidige problematiek rondom Lukas-Handelinge rekening gehou is nie. So ' $n$ indruk is onaanvaarbaar omdat die doel van hierdie studie nie is om op die huidige problematiek te konsentreer of dit volledig te behandel nie.

Vir die doeleindes van hierdie studie word die boek Handelinge beskou as 'n betroubare weergawe van wat waarlik gebeur het (vgl. 1980 : 21-22).

Die bogenoemde onderwerp stel bepaalde gesigspunte aan die orde, naamlik 'n begrensing ten opsigte van Handelinge, 'n gerigtheid op die werk van die Heilige Gees en 'n toespitsing op die opbou van die kerk.

Die veld van ondersoek word begrens deur op Handelinge te konsentreer. Hierdie afgrensing word van groot belang geag omdat verskeie studies oor die werk van die Heilige Gees en oor die opbou van die kerk uit die geheel van die Nuwe Testament gedoen is. Dit blyk uit 'n ondersoek van die literatuur dat daar nog nie 'n oorkoepelende studie oor die werk van die Heilige Gees in die opbou van die kerk net uit Handelinge gedoen is nie. Daar word dus doelgerig daarteen gewaak om die gegewens in Handelinge vanuit en in die lig van die ander besonderhede uit die $\mathrm{Ou}$ en Nuwe Testament te verklaar. 


\section{In die Skriflig}

Hierdie afgrensing beteken nie dat die eenheid van die Skrif nie in ag geneem word nie. Die verband met die res van die Skrifgegewens word slegs aangedui wanneer die feite in Handelinge dit vereis. So 'n afgrensing mag die waarde hê dat die gegewens in Handelinge (bv. die spreek in tale) nie in die lig van Paulus se briewe verklaar word nie, maar dat Handelinge self daaroor aan die woord kom.

Die tweede gesigspunt het op die Heilige Gees betrekking. Die werk van die Heilige Gees kan nouliks van die trinitariese bestaan van God losgemaak word. Die koninkryk van God (1:3), die belofte van die Vader $(1: 4)$ en die beskikking van die Vader $(1: 7)$ word aan die begin van Handelinge genoem en was klaarblyklik vir die koms en werk van die Heilige Gees van deurslaggewende betekenis. Die Gees kan ook nie los van Jesus Christus gesien word nie. Dit blyk reeds uit die doel van Handelinge, wat beskryf kan word as 'n verkondiging van die evangelie in 'n weergawe van hoe die dade en woorde van Jesus in die getuienis en dade van die apostels voortgesit is (Venter, 1980:23). Die verband tussen Jesus Christus en die werk van die Heilige Gees blyk ook reeds in die eerste hoofstuk van Handelinge $(1: 2,4,5,8)$. Maar dat die Gees ook 'n besondere en eiesoortige werk in die eerste Christelike kerk verrig het, word ook van die begin af in Handelinge aangedui. Hierdie werk van die Heilige Gees word hier behandel.

'n Studie wat op die werk van die Heilige Gees gerig is, is stellig van aktuele belang in die lig van die bestaan van die Neo-Pentekostalisme. Die werk van die Gees in die kerk soos in Handelinge beskryf, kan ook belangrike gegewens bied vir die betrokkenheid en geloofslewe van die hedendaagse gelowiges.

Daarom word op die opbou van die kerk toegespits. Opbou word gebruik

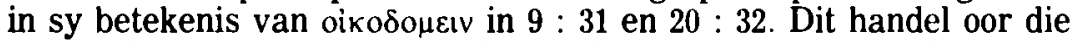
versorging van mense wat reeds aan die kerk behoort en is dus op die interne lewe van die gemeente gerig. Opbou word van die uitbou (uitbreiding) van die kerk onderskei, omdat laasgenoemde op mense wat nog nie aan die kerk behoort nie, toegespits is. Die feit moet in ag geneem word dat die verkondiging aan persone buite die kerk (uitbou) juis die begin mag wees van die proses waardeur mense deel van die kerk geword het - dit sou dus as die begin van hulle opbou as gelowiges gesien kon word. In hierdie verband word opbou en uitbou onderskei maar nie finaal geskei nie.

'n Opname uit die literatuur laat blyk dat daar tot dusver geen studie spesifiek oor die opbou van die kerk in Handelinge gedoen is nie. Noordegraaf (1984) behandel onder die term groei die opbou en die uitbou van die kerk (hoewel hy die twee begrippe ook van mekaar onderskei). Roberts (1963) behandel die opbou van die kerk, maar uit die "Efesebrief".

'n Studie oor die opbou van die kerk is tans van aktuele belang. Dit blyk uit die aandag wat teenswoordig aan die toerusting van ampsdraers en gemeentelede gegee word deur kursusse, kampe, lektuurverskaffing, Bybelstudie en soortgelyke aktiwiteite.

Die woord kerk en gemeente word in die volgende opsig van mekaar onderskei en soos volg hier gebruik. Die gemeente word beskou as die 
saamgroepering van gelowiges in Jesus Christus in 'n bepaalde gebied of op 'n bepaalde plek. In die huidige taalgebruik word van 'n plaaslike gemeente (of plaaslike kerk) gepraat wat onder leiding van voorgangers funksioneer. Die woord kerk word vir die doeleindes van hierdie studie gebruik om die wêreldwye kerk te benoem. Kerk sluit dus alle gelowiges in Christus in. Dit word gedoen in die besef dat die kerk van Christus inderdaad plaaslik funksioneer op die plek of plekke waar die gelowiges hulle bevind.

\section{OORSIG OOR DIE INHOUD}

Die inhoudsopgawe van die studie sien soos volg daar uit:

$1 \quad$ Verantwoording

1.1 Onderwerp en doel

1.2 Afgrensing

1.3 Noodsaaklikheid en aktualiteit

1.4 Algemene opset

1.4.1 Metode en inhoudelike oorsig

1.4.2 Begripsbepaling (opbou en kerk)

1.4.3 Tegniese besonderhede

$2 \quad$ Die Heilige Gees en die apostels

$2.1 \quad$ Die Heilige Gees en die roeping tot apostels

2.2 Aard en inhoud van die apostelskap

2.3 Krag vir die apostels met Pinkster

2.3.1 Die belofte van die $\mathrm{krag}$ in Hand $1: 8$

2.3.2 Die ontvangs van die krag in Hand $2: 1-4$

2.3.2.1 Historiese betroubaarheid

2.3.2.2 Wie met Pinkster teenwoordig was

2.3.2.3 Die betekenis van die tekens van Pinkster vir die apostels Geluid van 'n geweldige rukwind Tonge soos van vuur Praat in ander tale

$2.4 \quad$ Die Heilige Gees en die apostels se verkondiging

2.4.1 Die Heilige Gees lei en versterk die apostels

2.4.2 Die Heilige Gees gee aan die apostels vrymoedigheid

2.4.3 Die Heilige Gees as inhoud van die verkondiging

2.5 Die Heilige Gees en die apostels se leiding in die kerk

2.5.1 Gebede en ondersteuning

2.5.2 Praktiese inisiatief

2.5.3 Uitbreiding en eenheid

2.5.4 Handoplegging deur die apostels

2.5.5 Gesamentlike arbeid

$2.6 \quad$ Samevatting

3 Die Heilige Gees en die voorgangers in die gemeentes

3.1 Die verskillende dienste

3.1.1 "Die sewe"

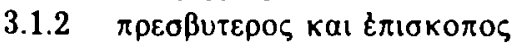

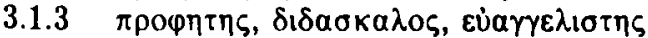

3.2 Die betekenis van die Heilige Gees vir die voorgangers oor die algemeen

3.2.1 Roeping tot die dienste 
3.2.2 Algemene opdrag van die voorgangers

3.2.3 Besondere aktiwiteite van die voorgangers

3.2.3.1 "Die sewe"

3.2.3.2 Wonders en tekens

3.2.3.3 Handoplegging

3.3 Die Heilige Gees en die vereistes aan die voorgangers gestel

3.3.1 Charisma en amp

3.3.2 Besondere eienskappe van die voorgangers

3.3.2.1 Wysheid van Stefanus

3.3.2.2 Geloof van Barnabas en Stefanus

3.3.2.3 Belesenheid, geesdrif en toewyding van Apollos

3.3.3 Vrymoedigheid, genade en $\mathrm{krag}$

3.3.3.1 Stefanus

3.3.3.2 Filippus

3.3.3.3 Apollos

3.3.3.4 Die ouderlinge

3.4 Samevatting

4 Die Heilige Gees en die individuele gelowige

4.1 Die Heilige Gees lei tot geloof

4.1.1 Die Heilige Gees werk volgens die inisiatief van Jesus Christus

4.1.2 Die doop met die Heilige Gees

4.1.3 Deur die prediking lei die Heilige Gees tot geloof

4.1.4 Die begin van die geloof

4.1.5 Die Heilige Gees lề die verband tussen die geloof en die doop

4.2 Die Heilige Gees begelei die gelowige

4.2.1 Geloof en bekering

4.2.2 Vervul met die Heilige Gees

4.3 Die Heilige Gees rus die gelowige verder toe

4.3.1 Gawes van die Heilige Gees

4.3.1.1 Die Heilige Gees as gawe

4.3.1.2 Buitengewone gawes van die Heilige Gees

Profesie

Praat in ander tale

Genesing, bose geeste, opwekking van dooies

Gevolgtrekking

4.3.2 Besondere eienskappe van die gelowige

4.3.2.1 Blydskap

4.3.2.2 Vrymoedigheid

4.3.2.3 Gehoorsaamheid

4.3.2.4 Betrokkenheid

4.3.2.5 Gevolgtrekking

4.4 Die Heilige Gees rig die godsdienstige aktiwiteite van die gelowige

4.4.1 Die Christelike lewenspatroon

4.4.2 Omgang met die Skrifte

4.4.3 Gebed

4.5 Samevatting

5. Die Heilige Gees en die plaaslike gemeentes

5.1 Die belangrikheid van Pinkster vir die gemeentes

5.1.1 Die betekenis van Jesus Christus en Pinkster vir die gemeentes

5.1.2 Gemeentevorming as doel van Pinkster 
5.1.3 Die vier elemente in Hand 2: $42-47$

5.2 Die Heilige Gees en die wesenskenmerke van die gemeentes

5.2.1 Die leer van die apostels

5.2.2 Die gemeenskap

5.2.3 Die breking van die brood

5.2.4 Die gebede

5.3 Die Heilige Gees en die voortbestaan van die gemeentes

5.3.1 Die stryd teen aanslae van binne die gemeentes

5.3.2 Die stryd teen aanslae van buite die gemeentes

5.4 Die Heilige Gees en die ordelike bestaan van die gemeentes

5.4.1 Die samekomste

5.4.2 Gesamentlike besluitneming

5.4.3 Ordelike praktyke

5.5 Samevatting

$6 \quad$ Die Heilige Gees en die wêreldwye kerk

6.1 Pinkster en die wêreldwye kerk

6.2 Verhouding plaaslike gemeente en wêreldwye kerk

6.3 Eenheid in die wêreldwye kerk

6.3.1 Jerusalem en die apostels en die Heilige Gees

6.3.2 Die verwerkliking van die eenheid

6.3.3 Die gemeentes beraadslaag saam

6.4 Samevatting

7 Slotsom

8 Terreine vir verdere ondersoek

9 Abstract

10 Bronnelys

11 Teksregister

\section{BEVINDINGS EN ENKELE DIEPTESNITTE}

Die aandag word daarop gevestig dat ' $n$ bevinding van die studie is dat daar in al die hoofstukke enkele deurlopende fasette is, naamlik 1. Die opbouwerk van die Heilige Gees moet as 'n deel van die dade en woorde van Jesus Christus gesien word.

2. Die opbouwerk van die Heilige Gees moet nie van sy trinitariese verband losgemaak word nie.

3. Die koms van die Heilige Gees op Pinkster was openbaringshistories die vertrekpunt vir die opbouwerk van die Gees en het die basis vir sy voortgaande werk in die kerk gebied.

4. Die Heilige Gees het die prediking van die apostels as die basis gebruik waarop die kerk opgebou is.

5. Die werk van die Heilige Gees het die kerk in dié mate opgebou dat die apostels, die voorgangers en die individuele gelowiges afsonderlik en gesamentlik in die gemeente self tot die woord en die daad oorgegaan het. Die voortgesette dade en woorde van Jesus Christus het deur die werk van die Heilige Gees die lede van die kerk self tot voortdurende woorde en dade gelei. So het Jesus Christus sy doel in en met sy kerk bereik.

\subsection{Die Heilige Gees en die apostels}




\subsubsection{Enkele dieptesnitte}

3.1.1.1 Praat in ander tale in Hand $2: 4$ e.v.

Weens die feit dat die praat in ander tale meermale in Handelinge genoem word, en omdat die praat in tale dikwels in studies en gesprekke genoem word, word 'n dieptesnit hieroor gemaak.

In die studie word aangetoon dat dit die waarskynlikste is dat die volle gemeente teenwoordig was toe die gebeure van Hand $2: 1-13$ plaasgevind het en dat die apostels in $2: 5$ - 11 veral na vore getree het om te praat en leiding te gee. Dit hou in dat die Heilige Gees op almal geval het, dat almal ook in ander tale gepraat het maar dat die leiers wat prominent na vore getree het die apostels ("Galileers" in $2: 7$ ) was.

Die woord $\gamma \lambda \omega \sigma o \alpha$ kom in Handelinge voor in $2: 3,4,11,26 ; 10: 46$; $19: 6$. In $2: 3$ en $2: 26$ gaan dit om die menslike tong en in die ander verse oor die taal. In $2: 6,8$ word die $\gamma \lambda \omega \sigma \sigma \alpha$ van $2: 4$ as $\delta ı \lambda \varepsilon \varepsilon \kappa \tau$ to aangedui. Die sinonieme gebruik van $\gamma \lambda \omega \sigma \sigma \alpha$ en $\delta ı \alpha \lambda \varepsilon \kappa \tau o s$ in Hand 2 blyk egter die duidelikste uit $2: 6,8(\delta, \alpha \lambda \varepsilon \kappa \tau o \varsigma)$ en $2: 11(\gamma \lambda \omega \sigma \sigma \alpha)$ waar dit duidelik blyk dat die praat in ander tale ( $\lambda a \lambda \varepsilon ı v \varepsilon \varepsilon \varepsilon \rho a 1 \varsigma \gamma \lambda \omega \sigma \sigma a ı \varsigma)$ in $2: 4$

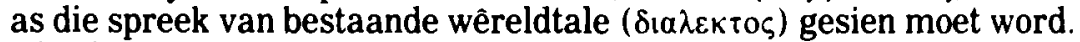
Hier is nie van onverstaanbare tale sprake nie. Hierdie tale was ook (ekstern) gerig op die mense buite die kerk, hoewel dit tog as gebeure vir die gelowiges (intern) baie sou beteken het. En dit het skynbaar net hierdie een geleentheid gebeur, onmiddellik na die gebeure van $2: 1$ 4. Dit was dus nie 'n voortgaande gawe nie (soos byvoorbeeld die profesie van die dogters van Filippus).

Dieselfde moet ook van $\gamma \lambda \omega \sigma \sigma a$ in $10: 46$ gesẻ word. Die inhoud daarvan was ook "die groot dade van God" (soos in $2: 11$ aangedui). Die feit dat "die gawe van die Heilige Gees" in 10:45 uit die praat in ander tale geblyk het, word deur $\gamma \alpha \rho$ aan die begin van v. 46 aangedui. Laasgenoemde was vir die gelowiges die bevestiging van eersgenoemde. As Petrus dan in v. 47 sé dat hierdie mense in Samaria die Gees ontvang het, $\dot{\omega} \varsigma \kappa \alpha \iota \grave{\eta} \mu \varepsilon \iota \varsigma$, dui dit nie net op die Heilige Gees nie maar ook op die $\gamma \lambda \omega o$ oal (tale) wat in $2: 4-11$ vir die apostels en andere die bevestiging was dat hulle wel die Heilige Gees ontvang het. Dit is daarom waarskynlik dat dit hier in $10: 46$ ook verstaanbare wêreldtale is wat uitgespreek

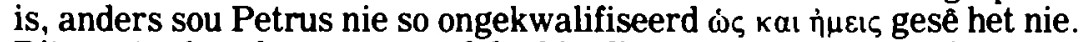
Dit moet ook onderstreep word dat hierdie $\lambda \alpha \lambda$ ouvt $\omega \vee \gamma \lambda \omega o \sigma a l s$ in $10: 46$ net 'n eenmalige gebeure was wat onmiddellik na $10: 44$ gevolg het en dus nie as 'n voortgaande gawe beskou kan word nie. Hierdie feit word daardeur bevestig dat die betekenis van hierdie gebeurtenis vir die voortgang van die kerk belangrik was. ' $n$ Nuwe groep word by die kerk gevoeg, hier in $10: 44$ - 48 en ook later in $19: 1-6$ (Grosheide, $1948 ; 200$ ). Die praat in ander tale het dan 'n besondere betekenis vir hierdie betrokke situasies: "It was a manifestation of God's acceptance of gentiles given for the benefit of prejudiced Christians" (Tolbert, 1974: 529).

Die enigste ander gedeelte waar $\lambda \alpha \lambda \varepsilon$ เv $\gamma \lambda \omega o \sigma a ı$ in Handelinge voorkom is in $19: 6$. In die lig van die bogenoemde verklaring van die verskynsel in $2: 4-11$ en $10: 46$ is dit hoogs waarskynlik dat ook hier die praat in ander tale net aan die betrokke gebeure van $19: 1-6$ verbina was en ook nie 'n voortgaande gawe was nie. 
Toe almal in Hand $2: 24$ vervul is ( $(\varepsilon \pi \lambda \eta \sigma \theta \eta \sigma \alpha v \pi \alpha v \tau \varepsilon \zeta)$ met die Heilige Gees, het hulle in ander tale begin praat soos die Gees aan hulle gegee het om uit te spreek (vgl. studie 4.3.1.2).

Die plotselinge en ingrypende betekenis van wat hier gebeur, word deur

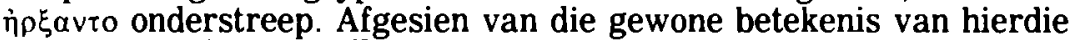
woord, naamlik dat hulle "begin" het om te praat, dus 'n nuwe aksie aan die gang gesit het, word hier 'n ingressiewe aoristus gebruik. Hier is sonder twyfel van 'n dramatiese nuwe wending sprake. Wat nou volg, is die regstreekse en eerste vrug van die uitstorting van die Heilige Gees. Die tekens van die geluid en die tonge bly nie in die lug hang nie maar het effektiewe betekenis. Die Heilige Gees het gekom sodat die gelowige sal praat en werk. "Dat de Geest er is en werkt, is het primaire, dat er gesproken wordt, het secundaire" (Adler, aangehaal deur Grosheide, $1942: 51$ ).

Die wonder hiervan was 'n spreekwonder, want die klem val in v. 4 op

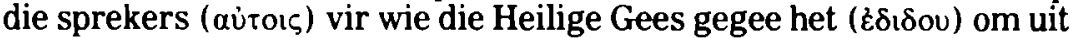
te spreek $(\alpha \pi \circ \varphi \theta \varepsilon \gamma \gamma \varepsilon \sigma \theta a \mathrm{i})$. Die klem val deurentyd op die vergaderdes (sprekers) van v. 1 - 4 en nie op die omstanders (hoorders) van v. 5 - 11 nie.

Die besondere krag wat die dissipels ontvang het, sou geblyk het uit die geesdrif, selfs ekstase, waarmee hulle sou gepraat het onmiddellik na so ' $n$ besondere en sigbare vervulling met die Heilige Gees. Maar dit moet nie as ekstatiese brabbeltaal verstaan word nie hoewel hulle geesdriftige optrede dalk as verklaring kan dien waarom die onbetrokke omstanders hierdie ekstatiese opgewondenheid vir dronkenskap aangesien het (v. 13). Eerder bestaan die wonder daarin dat die Heilige Gees dit in die dissipels gegee het om in ander, verstaanbare wêreldtale (vgl. v. 9 - 11) te praat (vgl. studie 4.3.1.2). Die omstanders het duidelik verstaan wat gesê is (anders as die glussolalia van 1 Kor 12 - 14). So word dit duidelik dat ". . . die prominentse effek van die ontvangs van die Heilige Gees is dat die apostels aan elke afsonderlike volk die evangelie in sy eie taal verkondig"' (Coetzee, 1965:269).

Die apostels was nou nie meer net toeskouers (van 'n geluid en van tonge) nie maar het die inwendige krag van die Heilige Gees ontvang deur self in ander tale te praat. Op hierdie wyse het die apostels die werklike van die Heilige Gees ervaar en was hulle seker dat Jesus sy belofte van $1: 8$ gestand gedoen het. Hulle was nou toegerus om die opdrag wat hulle van Jesus Christus ontvang het, uit te voer.

Dit kan beskou word as die beginpunt van die apostels se werk om die kerk van Christus uit te bou en op te bou.

\subsubsection{Enkele kernwoorde in Handelinge}

In Handelinge word sekere woorde herhaaldelik gebruik om die besondere leiding van die Heilige Gees aan te dui.

Die woord à $\pi \circ \varphi \varepsilon \gamma \gamma \gamma \varepsilon \sigma \theta a$, wat in $2: 4$ gebruik word om die "praat" van die apostels tydens die Pinkstergebeure te benoem, is veelbetekenend vir die werk van die Heilige Gees in die apostels. Hierdie woord dui op ekstatiese orakels en is ' $n$ aanduiding van ' $n$ besondere inspirasie van die Gees (vgl. $2: 14 ; 26: 25$ ). Die werk van die Heilige Gees in die apostels blyk ook in $4: 8$ waar Petrus "vervul met die Heilige Gees" praat (vgl. $9: 17$ ). 
Die vrymoedigheid ( $\pi \alpha \rho \rho \eta \sigma i)$ waarmee die apostels opgetree het, blyk uit $4: 13$. In die lig van $4: 8$ is Petrus se optrede deur sy vervulling met die Heilige Gees bepaal. Hierdie leiding van die Gees word in $4: 31$ bevestig. Ook ander mense kon sien dat die Heilige Gees die krag in die apostels was en dat Hy hulle tot vrymoedigheid opgebou het.

'n Soortgelyke vrymoedigheid was by Paulus merkbaar volgens $9: 27$, 28. In $9: 17$ word deur Ananias genoem dat Paulus met die Heilige Gees vervul word; daarna verkondig hy Jesus $(9: 20,22)$ en hierdie ver-

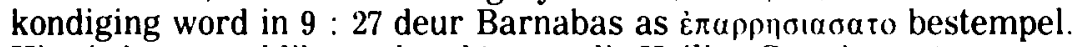
Hier is 'n oorsaaklike verband tussen die Heilige Gees in $9: 17$ en vrymoedigheid in $9: 27$. Paulus het, blykens $28: 31$ tot aan die einde toe met volle vrymoedigheid ( $\mu \varepsilon \tau \alpha$ maon $\pi \alpha \rho \rho \eta \sigma i a \varsigma$ ) die woord verkondig en geleer.

Hierdie vrymoedigheid waarmee die apostels opgetree het, was die sigbare getuienis van die feit dat Jesus deur hulle aan die werk was. Hulle is so deur die Heilige Gees opgebou en versterk dat hulle woorde op sigself dade was, ' $n$ lewende getuienis van die krag in hulle.

\subsection{Die Heilige Gees en die roorgangers in die gemeentes}

\subsubsection{Enkele dieptesnitte}

\subsubsection{1 "Die sewe"}

Die sewe manne wat as groep as "die sewe" bekend sou staan $(21: 8)$, word in $6: 1-6$ aangewys. Die woord sıanovia word in hierdie verse telkens gebruik $(6: 1,2,4)$ maar moet nie daarom vanselfsprekend met die woord 'diaken' vereenselwig word nie, soos byvoorbeeld deur Sillevis-Smitt (1910: 67) gedoen is. Tans word redelik algemeen aanvaar dat "die sewe" se taak veel breër gesien moet word (o.a Coetzee. 1967 44-50; Floor, 1976: $25-27$; Gerritsen, 1953: 65; Davies, $1965: 47$; Lekkerkerker. $1971: 120)$.

Die woord sianovia word in 'n nog wyer betekenis gebruik as dit bloot vir "diens in die algemeen" gebesig word (bv . $1: 17,25 ; 12: 25 ; 20: 24$; $21: 19)$. In laasgenoemde betekenis word $\delta$ arovia in $6: 1$ aangewend (Grosheide, $1942: 193)$.

In $6: 2$ word van $\delta$ เ коvєıv т $\rho \alpha \pi \varepsilon \zeta \alpha \iota \zeta$ gepraat, wat op 'n spesifieke "versorging" dui, naamlik "om die tafels te bedien". Hierdie fiakovia is as deel van die apostels se werk gesien (Grosheide, 1942 : 195: Haenchen, 1971 262: Marshall, $1980: 126$ ), maar dit beteken nie dat die apostels fisiek alles alleen sou gedoen het nie. Dit sou prakties onmoontlik wees in 'n gemeente wat (volgens Lenski, 1961 : 239) dalk oor die 20000 lidmate gehad het. Dit neem nie weg nie dat dit die apostels se verantwoordelikheid was om beheer oor hierdie siakovia uit te oefen.

Blykens $6: 1$ - 6 was die eendragtigheid van die gemeente $(2: 45,46)$, wat tot dusver daagliks ( $\kappa \alpha \theta \eta \mu \varepsilon \rho ı \eta$ in $6: 1$ ) onder leiding van die apostels metterdaad beoefen is, baie belangrik. Toe "die sewe" aangestel is, het dit vir die opbou van die gemeente baie beteken. Dit wat die eendragtigheid bedreig het en die opbou van die gemeente kon versteur, naamlik die yorrvoros van die Griekssprekendes, kon nou uit die weg geruim word. Die opbou van die gemeente kon nou ongehinderd

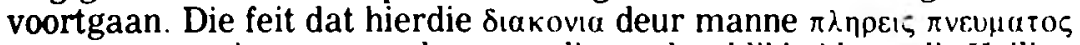
$\kappa \alpha \lambda$ оофı $\zeta$ verrig moes word, wys op die noodsaaklikheid van die Heilige 
Gees se werk in die $\delta \_$кov $\alpha$ van hierdie manne. Hier word die betrokken-

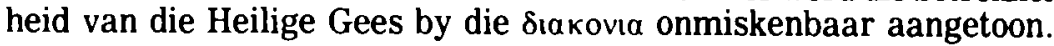

Dit moet ook onderstreep word dat hierdie besondere diens op die interne funksionering in die gemeente gerig was. Dit gaan om die opbou van die gemeente self, alhoewel die persone (bv. Stefanus in $6: 8-7: 60$ en Filippus in $8: 26-40$ ) ook soms na buite gewerk het.

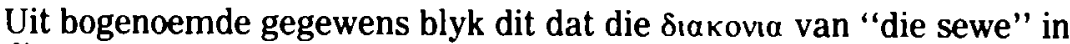
die gemeente grotendeels intern op die opbou van die gemeente gerig was (hoewel dit nie eksklusief daartoe beperk moet word nie) en dat die Heilige Gees in die uitoefening van hierdie diens ' $n$ bepalende rol vervul het.

Daar moet verder bepaal word wat die verhouding van "die sewe" tot die "ampte" van ouderling en diaken is soos dit uit die briewe van Paulus bekend is en tans nog in die kerk in swang is. Die gevaar is dat daar vanuit bepaalde "strukture" of "ampte" na die taak van "die sewe" gekyk word. In 'n poging om onbevange hieroor ondersoek te doen word die bedoeling van Handelinge as vertrekpunt geneem, naamlik om die voortgesette dade en woorde van Jesus in die woorde en dade van die kerk uiteen te sit. Die klem moet dan op Jesus Christus val en nie op die mense nie. Dit gaan in $6: 1$ - 6 primêr om Jesus se regering, wat op alle gelowiges in die kerk betrekking het en deur niks belemmer moet word nie. Dit was die dryfveer agter die besluit van die apostels dat sewe manne gekies moet word. In die mate is die Heilige Gees ook hier betrokke, want Hy was die "belofte van die Vader" (1:4;2:33), deur Christus gestuur, om die krag (1:8) aan die apostels te gee sodat Christus reg gedien kan word.

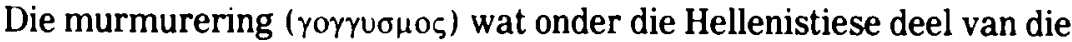
gemeente ontstaan bet, was 'n skending van Christus se heerskappy in die kerk. Daarom moet Davies (1965 : 47) gelyk gegee word as hy die verband met die sewentig oudstes van Num $11: 11-17$ aantoon. Hier is ook sprake van 'n murmurering van die volk oor die voorsiening van voedsel (vgl. ook Eks $15: 24 ; 16: 2 ; 17: 3$, waar in die Septuaginta ook

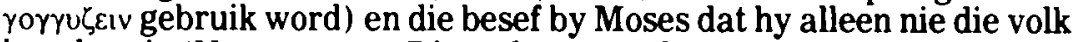
kan dra nie (Num $11: 14$ ). Die oudstes wat dan aangewys word, handel nie net oor kosvoorsiening nie maar staan Moses by om die volle leiding van die volk waar te neem. Hierdie murmurering was in wese 'n opstand teen God (Rengstorf, 1964: 730). So sorg die Here in Numeri dat die volk, wat van hulle kant die Here verwerp het (Num 11:20), op die regte wyse gelei word. Handelinge 6 is dus nie net oor die skep van 'n amp begaan nie maar wel oor die regte verhouding van die gemeente tot Christus. Hierdie verhouding is deur die murmurering teen die Hebreers versteur: $\pi \rho \circ$ met die akkusatief wys duidelik dat die beswaar teen die Hebreërs gerig was. Hier is dus sprake van 'n sterk gevoel tussen twee groepe in die gemeente (Coetzee. 1967: 46).

As $6: 3$ dus van "hierdie nodige saak" melding maak, handel dit oor die volle saak soos hierbo uiteengesit en nie net oor armversorging nie. Dit beteken dat die beginsel gestel in $6: 1-6$ nie die van die instelling van 'n amp is nie maar dat, sodra gesien sou word dat iets in die gemeente die Koningskap van Christus aantas, daar persone aangewys behoort te word om daarna om te sien. Die werk van "die sewe" was 


\section{In die Skriflig}

dus nie 'n aftakking van die apostels nie (soos by Koole, 1949:77) of 'n deel van die ouderlingeamp nie (soos by Floor, $1976: 25$; Gerritsen, $1953: 65$ ) maar 'n selfstandige opdrag om "die gemeenskapslewe wat . . . bedreig is" (Van Wyk, 1982: 49), weer te herstel.

In Handelinge 6 word nie gesê of dit behels het dat "die sewe" oor die breking van die brood en dus "regerende toesig oor die bediening van die sakramente" (Coetzee, 1967: 47 - 48) gehad het nie. Hulle was ook nie die leierskorps van 'n sekere groep van die gemeente (naamlik die Helleniste) nie (Conzelmann. $1978: 44$ : Goppelt, 1980:54) maar is oor 'n bepaalde saak aangestel: $\dot{\varepsilon} \pi ı$ met die genitief dui daarop dat hulle beheer "oor" die saak moes neem (vgl. Coetzee, $1967: 47$ ), en hierdie saak het die hele gemeente geraak. Hulle moes dus die hele gemeente bedien het soos hulle deur die hele gemeente gekies is (Sillevis-Smitt, 1910:150).

Die besondere opdrag van hierdie sewe manne is gedoen in die besef van hulle afhanklikheid van die Heilige Gees. Daarom moes hulle met die Heilige Gees vervul wees (6:3). Die feit was dat die vol wees van die Heilige Gees vir ander mense herkenbaar was, sodat die gelowiges noukeurig daarvoor moes oplet ( $\dot{\varepsilon} \pi \sigma \kappa \varepsilon \varphi \alpha \sigma \theta \varepsilon$ in $6: 3$ is 'n aoristus imperatief).

\subsubsection{Filippus se verkondiging}

Die wyse waarop Jesus Christus deur die Heilige Gees toesien dat die Skrif verkondig word, blyk duidelik uit $8: 26$ - 40 as die volgende saaklike gedagtestruktuur uiteengesit word: Vergelyk skets 1 .

Uit hierdie uurglaskomposisie (vgl. Coetzee, 1983: 16) blyk die voortgang van die evangelie (1), uit die bekering van die ontmande Etiopier (2). Van 'n onsekere, ongelukkige persoon (v. 27b) word hy tot 'n gelukkige gedoopte gelowige (v. 39b). Die Heilige Gees se werk is baie prominent (3) as Hy Filippus stuur (v. 29) en wegneem (v. 39a). Die Heilige Gees se inisiatief (3) omsluit Filippus se Woordverkondiging (5) as antwoord op die vraag van die Etiopier (v. 31a; 32 - 34) wat tot sy geloof en doop lei (4). Die verkondiging van Jesus vanuit die Skrif (Jesaja) staan kenlik in die sentrum (5), maar die werk van die Heilige Gees skep die brug vir die toegang wat Filippus tot die Etiopier gehad het (3).

3.3 Die Heilige Gees en die individuele gelowige

Enkele dieptesnitte

In Handelinge word die volgende uitdrukkings gebruik om aan te dui dat die Heilige Gees op een of ander wyse in die gelowiges werk: "gedoop met die Heilige Gees", "die Heilige Gees is gegee". "vervul met die Heilige Gees", "vol van die Heilige Gees", "die Heilige Gees as gawe gegee", "die Heilige Gees ontvang", "die Heilige Gees wat op hulle val", "die Heilige Gees wat uitgestort word", "die Heilige Gees wat oor hulle kom".

Enkele dieptesnitte hieroor word nou gedoen.

3.3.1 Die doop met die Heilige Gees

Die woorde "doop met die Heilige Gees" kom in Handelinge slegs in $1: 5$ en $11: 16$ voor. Hierdie twee verse hou in wese met dieselfde saak verband omdat $11: 16$ na $1: 5$ verwys. Hieruit blyk 'n baie beperkte gebruik van hierdie uitdrukking in Handelinge. Die briewe van Paulus kan moontlik 'n wyer en ander betekenis daaraan heg (waarop nie hier ingegaan word nie). 
1 'n Engel van die Here stuur Filippus, en Filippus gehoorsaam.

2 Die ontmande Etiopier reis in onsekerheid, en hy lees uit Jesaja.

3 Die Gees sê vir Filippus om op die wa te klim, en hy gehoorsaam.

4 Filippus vra: Verstaan jy? Die Etiopiër sê: Hoe kan ek?

5 Hy nooi Filippus uit, en vra: Van wie praat Jesaja?

5 Filippus verkondig Jesus uit die Skrifte. Die Etiopier glo in Jesus, en

4 hy word gedoop.

3 Die Gees voer Filippus weg.

Die gedoopte Etiopiër rels met blydskap.

Filippus verkondig die evangelie verder.

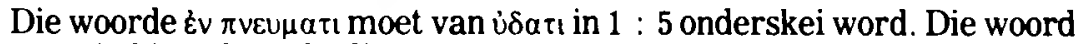

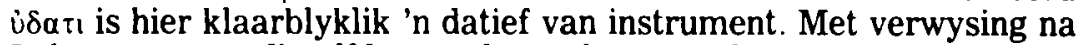
Luk $3: 16$, waar dieselfde woorde voorkom, word $\xi v \pi v \varepsilon v \mu \alpha \tau$ as 'n datief van die persoon beskou. Die betekenisverskil tussen Gees en water bevestig hierdie onderskeiding: daar kom 'n uitsonderlike band met die Gres tot stand, anders as met die water. Die hoofsaak in $1: 5$ is dat die tw'ee inhoude van die doop verskil. Die gebruik van $\mu \varepsilon v . . \delta \varepsilon$ versterk die feit dat dit nie Johannes en die Heilige Gees is wat teenoor mekaar staan nie, maar die doop van Johannes teenoor dit wat "julle" met die nuwe doop sal ontvang.

Die openbaringshistoriese betekenis van $1: 5$ en $11: 16$ blyk uit die feit dat die Heilige Gees in $2: 1$ - 4 op hulle "uitgestort" is $(2: 33)$. Volgens Petrus (in $11: 16$ ), waar hy na die gebeure in $10: 44-48$ aan huis van Kornelius verwys, was $2: 1-4$ en $10: 44$ - 48 beide 'n doop met die Heilige Gees. Petrus sẽ met groot sekerheid dat die gebeure in $10: 44$ 48 ooreenstem met $2: 1-4:$ "soos op ons in die begin" (11:15) en "net soos ons" (11:17).

Die doop met die Heilige Gees is in Handelinge hierdie aanbreek van 
die nuwe aeon in $2: 1$ - 4 en die deurbreek daarvan na die $\varepsilon \theta \vee \eta$, die gelowiges uit die heidennasies in $10: 44-48$.

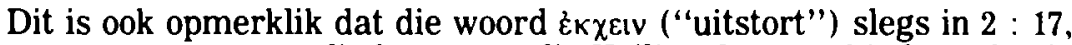
18,33 en $10: 45$ aan die koms van die Heilige Gees verbind word. Die kerk is met die Heilige Gees "gedoop". In $2: 17,18$ word na die profesie van Joèl verwys en aangetoon dat dit wat in $2: 1$ - 4 e.v. gebeur het, kennelik die aanbreek van "die laaste dae" $(2: 17)$, die nuwe aeon, was. Hierdie "doop met die Heilige Gees" was dus inderdaad 'n openbaringshistoriese daad.

Dit beteken nie dat die doop met die Gees nie ook ' $n$ ingrypende implikasie vir die betrokke persone se eie geloofslewe gehad het nie. Dit het deur hulle en in hulle gebeur. In hierdie opsig sou die mense wat in $2: 1$ - 4 en $10: 44$ - 48 deel van die gebeure was, se belewing kon ooreenstem met die belewing van ander gelowiges wat op ' $n$ ingrypende wyse die Gees ontvang het $(2: 38-41 ; 8: 15-17 ; 19: 6)$. Maar hierdie ooreenkoms in "belewing" kan nie deurslaggewend wees om die doop met die Heilige Gees in Handelinge en bv. die "ontvang van die Gees" gelyk te stel nie. Trouens, die persone wat in $2: 1$ - 4 met die Gees gedoop is, was reeds gelowiges in Jesus Christus. Hulle het reeds voorheen die Gees gehad.

Die verskil in die werk van die Gees in die gelowiges van $2: 1-4$ is dan nie dat hulle voor Pinkster die Gees in 'n mindere mate gehad het nie. Die verskil lê eerder in die posisie van Jesus Christus. Hy het nou as verhoogde Here, volgens die belofte van die Vader, 'n nuwe fase in die lewe van die kerk ingelui. Van hierdie nuwe fase in die geskiedenis was die doop met die Gees die aanbreekpunt.

\subsubsection{Die begin van die geloof}

Omdat die boek Handelinge die aanvanklike begin van die kerk van Jesus Christus vermeld, word dikwels genoem dat mense die eerste keer tot geloof gekom het $(0 . a .2: 37-41,47 ; 5: 14 ; 8: 6-17,26-39 ; 9: 1$ 19). Hoe mense tot die geloof in Christus gekom het, word in $2: 37$ $41 ; 8: 6-17 ; 10: 44-48$ en $19: 1-7$ aan die werk van die Heilige Gees verbind.

Dit is opvallend dat $\lambda \alpha \mu \beta a v \varepsilon i v$ by elkeen van die vier gedeeltes voorkom $(2: 38 ; 8: 15,17,19 ; 10: 49 ; 19: 2)$ om aan te dui dat die Gees "ontvang" word. In $8: 16$ en $10: 44$ (vgl. $11: 15$ ) word $\varepsilon \pi \iota \pi \iota \tau \varepsilon ı$ gebruik

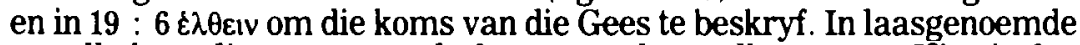
gevalle kom die voorvoegsel of voorsetsel $\varepsilon \pi$ telkens voor. Hier is dus 'n groot mate van eenvormigheid in uitdrukking. Dit was die begin van hulle geloofslewe as deelgenote aan die kerk van Christus.

In bogenoemde vier gedeeltes word meegedeel hoe die betrokke mense heilsordelik deel gekry het aan die openbaringshistoriese feit dat die kerk van Christus met die Heilige Gees gedoop is.

Een van die mees omstrede situasies in hierdie verband is die gebeure in Samaria volgens $8: 5-17$. Die sake waarom dit gaan is of Simon die Towenaar waarlik geglo het, dus die saligmakende geloof gehad het (veral gesien sy optrede in $8: 18-24$ ); moet dieselfde van die ander inwoners van die stad in Samaria gesê word, wat dan impliseer dat hulle 
eers waarlik begin glo het nadat die apostels later die hande op hulle gelê het $(8: 17)$ en dat hulle toe eers die Heilige Gees ontvang het?

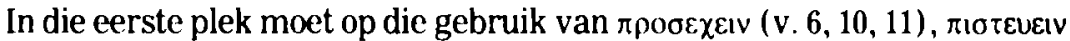

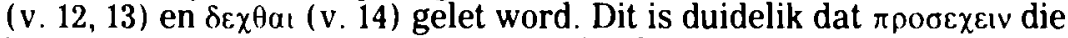
inwoners se aanhang van Simon beskryf (v, 10, 11) in kontras met $\pi ı$ reveıv in v. 12 waarmee die geloof in die verkondigde evangelie aangedui word.

Wat $\delta \varepsilon \chi \theta \alpha$ betref, moet daarop gelet word dat dit ook in ' $n$ algemene $(17: 11)$ en besondere $(11: 1)$ sin elders in Handelinge gebruik word. In $17: 11$ word daarmee nie die saligmakende geloof bedoel nie, want eers in $17: 12$ word gesê dat sommige van die wat die woord ontvang het ( $\dot{\varepsilon} \delta \varepsilon \xi \alpha \nu \tau o)$, daarin geglo het ( $\dot{\pi}\lrcorner \sigma \tau \varepsilon \cup \sigma \alpha v)$. In $8: 14$ en $11: 1$ gaan dit wel om die gelowige aanneem van die woord. Veral hier in $8: 14$, waar

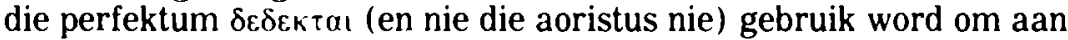
te dui dat die Woord van God nog steeds aangeneem is, dui daarop dat hier ' $\mathrm{n}$ voortgang is van die proses wat vantevore begin het (in v. 12).

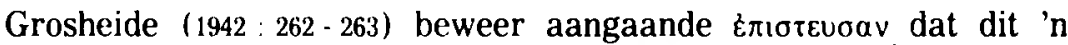
ingressiewe gebruik van die aoristus is, wat dan beteken: hulle het begin

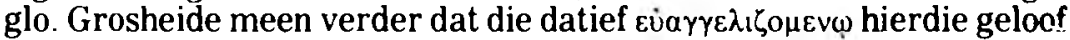
aandui as ' $n$ eerste verandering (ibid.: 263). Hy bring egter nie in berekening dat $16: 34$ (perfektum met datief) opregte geloof aandui nie. Daarom mag die gebruik van die datief in $8: 12$ nie as aanduiding van 'n 'eerste verandering"' beskou word nie.

Die draagwydte van die geloofsinhoud by die Samaritane en by Simon word in sy volle omvang besef as 'n gedagtestruktuurontleding van $8: 9-13$ gemaak word. Vergelyk skets 2

Die volgende afleidings word uit hierdie tipiese uurglaskomposisie (Coetzee, 1983: 16) gemaak:

1. Die geloof van die Samaritane (v. 12a) verskil wat inhoud betref, radikaal van hulle verbystering oor Simon se wonders (v. 11).

2. Die kernpunt van hierdie gebeure wentel enersyds om v. 11 en 12 en ook v. 9 en 13, wat beklemtoon dat Handelinge hier wil aandui dat daar by hierdie ongelowiges ware geloof tot stand gekom het.

3 . Vir so ' $n$ ingrypende verandering is alleen God verantwoordelik en sou die Heilige Gees reeds in hierdie stadium 'n bepalende rol vervul het in die ontstaan ( $\left.\dot{\varepsilon} \pi \_\tau \varepsilon \cup \alpha \vee v .12\right)$ en voortbestaan ( $\left.\delta \varepsilon \delta \varepsilon \kappa \tau \alpha \iota-v .14\right)$ van hierdie geloof.

4. Die kardinale belang van die kernpunt (naamlik die geloof) word deur die volgende onderstreep:

4.1 die verandering in Simon se lewensbenadering: eers dink hy dat hy self groot is (v. 9). later verstom hy hom aan die groot tekens en wonders van Filippus (v. 13);

4.2 die verandering in Simon se lewensituasie: hy gaan rond en doen wonders (v. 9), en later word hy gedoop on volg hy Filippus (v. 13); 4.3 die inwoners van Samaria, wat in die bree deur Simon se wonders beindruk word (v. 10a) maar individueel deur die doop betrek word (v. 12c); 


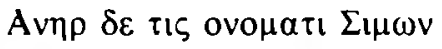

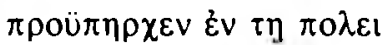

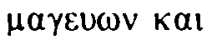

$\dot{\varepsilon} \xi_{\iota \sigma} \tau \alpha v \omega v$

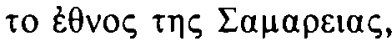

$\lambda \varepsilon \gamma \omega \vee \varepsilon I v \alpha \iota$ tıv $\alpha \dot{\varepsilon} \alpha \cup \tau o v \mu \varepsilon \gamma \alpha \nu$,

10

$\omega \pi \rho 0 \sigma c l \chi o v$

$\pi \alpha \nu \tau \varepsilon \varsigma \dot{\alpha} \pi \mathrm{o} \mu \mathrm{i \kappa \rho ov} \varepsilon \omega \varsigma \mu \varepsilon \gamma \alpha \lambda \mathrm{\alpha}$

$\lambda \varepsilon \gamma o v \tau \varepsilon \zeta$,

Oútos k̇otıV

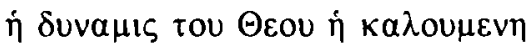

M $\varepsilon \gamma \alpha \lambda \eta$

$\pi \rho o \sigma \varepsilon i \chi o \nu \delta \varepsilon$

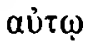

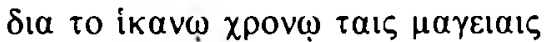

$\varepsilon \xi \varepsilon \sigma \tau \alpha \kappa \varepsilon v a l$ aủtous.

12

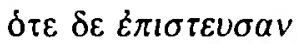

$\tau \omega \Phi 1 \lambda ı \pi \pi \omega \varepsilon \dot{U} a \gamma \gamma \varepsilon \lambda{ }_{1} \zeta o \mu \varepsilon v \omega$

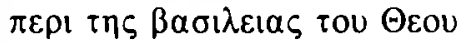

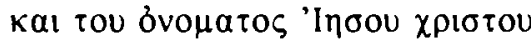

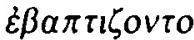

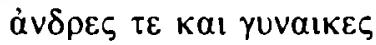

13

$\delta \delta \varepsilon \Sigma 1 \mu \omega v$

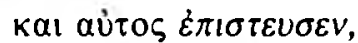

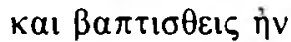

$\pi \rho \circ \sigma \alpha \alpha \rho \tau \rho \omega \vee \tau \omega \Phi_{1} \lambda i \pi \pi \omega$,

$\Theta \varepsilon \omega \rho \omega v \tau \varepsilon$

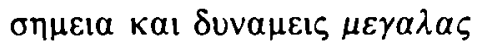

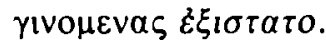

4.4 Simon vind dit nodig dat hy homself as groot voorhou ( $\mu \varepsilon \gamma \alpha \lambda \eta$ in v. 10b), terwyl die skare volgens v. 12b gebring word tot geloof in die koninkryk van God en die Naam van Jesus Christus, wat self groot is en so deur Filippus verkondig is (v. 5 en 12).

Uit bostaande gegewens blyk dit dat hierdie Samaritane en Simon reeds die ware geloof in Jesus Christus (v. 16) gehad het voor Petrus en 
Johannes se optrede in v. 14 - 17 (vgl. Floor, $1979: 48$ Marshall, 1980 : 157 - 8). Wat in v. 14 - 17 vermeld word, stem dus in 'n groot mate ooreen met die posisie van die dissipels in Hand $2: 1-4$ : hulle het ook reeds die ware geloof in Jesus Christus gehad, en tog is die Heilige Gees op Pinkster op hulle "uitgestort".

Hier in $8: 14-17$ is dit 'n nagolwing van Pinkster (Kruger, 1981 : 42) om aan te toon dat hulle waarlik deel van die kerk was (Grosheide, $1942: 266$ ) en dus volledig een was met die kerk in Jerusalem (Marshall, $1980: 157$ ). Die handoplegging van die apostels was dus nie 'n "metode" om die Heilige Gees uit te stort nie maar teken van hierdie eenheid in die Christelike kerk. Die gebed van die apostels in $8: 15$ was dan nie 'n gebed waar die Samaritane in die middelpunt is nie. Dit gaan meer om die opdrag van 1:8 en 'n gebed dat God se Gees moes aandui dat dit nou wel die tyd was wat Christus wou hê dat die evangelie ook in Samaria verkondig moes word (vgl. Grosheide, $1942: 266$ ).

Die blyk elders in Handelinge dat die Heilige Gees nie pertinent tydens die ontstaan van die geloof genoem word nie (vgl. $8: 37 ; 11: 21 ; 14: 1$; $16: 15,34 ; 17: 12,34 ; 18: 8$ ). By 'n ander geleentheid word die werk van die Heilige Gees genoem sonder om pertinent te meld dat die geloof ontstaan het ( $10: 44-48$; vgl. ook $\delta 1 \delta$ oval in $15: 8$ ). Dit bevestig die feit dat die Heilige Gees by die ontstaan van geloof betrokke is. Dit mag nie beweer word dat dit nie 'n ware geloof sou wees as die Heilige Gees nie by name in die betrokke geval genoem word nie.

Uit bogenoemde gegewens is dit duidelik dat die Heilige Gees die ware geloof in die individuele gelowige werk.

\subsubsection{Vervul met die Heilige Gees}

Twee woorde word in Handelinge gebruik om die besondere werking van die Heilige Gees in die individuele gelowige te beskryf, naamlik

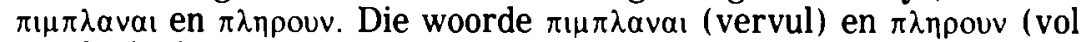
maak) is die enigste twee woorde wat in Handelinge saam met "die Heilige Gees" gebesig word om "vervul met die Heilige Gees" of "vol van die Heilige Gees" weer te gee. Eersgenoemde woord word in $2: 4$; $4: 8 ; 4: 31 ; 9: 17$ en $13: 9$ gebruik om "vervul met die Heilige Gees"; aan te dui. Laasgenoemde woord kom in $6: 3 ; 6: 5 ; 7: 55 ; 11: 24$ en $13: 52$ voor.

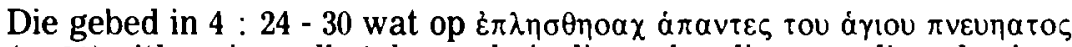
(v. 31) uitloop is veelbetekenend vir die verhouding van die gelowiges tot God. Hulle besef die nood van die situasie as gevolg van die vervolginge ( $4: 21$ ), en daarom bid hulle tot die $\delta \varepsilon \sigma \pi о \tau \alpha$ (v. 24) en кupı (v. 29) dat die apostels (vgl. $2.4 ; 5.2 .4$ ) die $\pi \alpha \rho \rho \eta$ øa sal hê om die woord te spreek $(\lambda \alpha \lambda \varepsilon i v$ - 'n duratiewe infinitief volgens Lenski, (1961: 183) en tekens en wonders "deur die Naam van u heilige Dienaar Jesus" ( $v$. 30) sal plaasvind. Hulle bid dus hier tot God (die Vader), in wie se "diens" ( $\pi a 1 \delta o \zeta$ in v. 30) Jesus is. Hier bely hulle dat die Vader se beloftes ( $1: 4)$ die agtergrond van die werk van Jesus is. Dit is die grondslag van alle opbouwerk van Jesus en die Heilige Gees. Hulle kan hulle in tyd van nood hierop beroep. Die feit dat hulle bid om $\pi \alpha \rho \rho \eta \sigma a$ vir mense wat dit volgens $4: 13$ opsigtelik gehad het en volgens $4: 8$ wel

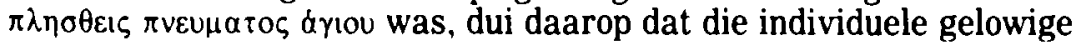


wat die Heilige Gees het, ook nog verder deur die Heilige Gees opgebou moet word. Dit word deur die Here self bevestig as Hy, volgens v. 31, almal ( $\dot{\alpha} \pi \alpha v \tau \varepsilon \varsigma)$ met die Heilige Gees vervul ( $\dot{\varepsilon} \pi \lambda \eta \sigma \theta \eta \sigma \alpha v)$ het sodat hulle

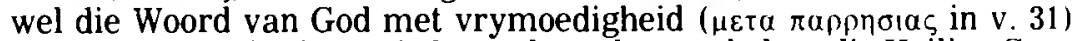
gespreek het. Hier is van 'n besonder opbouwerk deur die Heilige Gees sprake. Dit is God wat dit doen. Dit het hierdie gelowiges, wat reeds die Heilige Gees gehad het, kragdadig versterk en opgebou. Kruger ( $1981: 39$ - 40) noem dit ' $n$ tydelike versterking. Dit het nie beteken dat hulle die Heilige Gees voor die tyd onvolledig besit het nie, maar wel dat hulle besondere krag vir 'n besondere situasie nodig gehad het en dat die Heilige Gees hulle met hierdie krag opgebou het.

Wat $\pi \iota \pi \lambda \alpha$ va betref, is dit opmerklik dat die vervulling met die Heilige Gees telkens verbind word met 'n gebeurtenis waar daar "gepraat" word: $2: 4: \lambda \alpha \lambda \varepsilon ı v 4: 8: \dot{\varepsilon} ı \pi \varepsilon v ; 4: 31: \dot{\varepsilon} \lambda \alpha \lambda$ ouv; $9: 17$ : Paulus geroep om te verkondig - vgl. die besluit van die Here in $9: 15$ en غ̇кприб in $9: 20$ (Green, $1975: 151$ ) $; 13: 9: \dot{\varepsilon}$ เ $\pi \varepsilon v$ in $4: 8$ en $13: 9$ is dus 'n tipiese voorbeeld van die besondere vervulling met die Heilige Gees, veral waar dit die gesproke woorde van die apostels geraak het. Dit geld ook van $2: 4$ en $4: 31$, terwyl $9: 17$ meer algemeen is wat die situasie betref maar tog besonder wat Paulus se persoon en toekomstige taak aangaan.

Ten opsigte van die woord $\pi \lambda$ npouv is daar iets anders opmerklik, naamlik dat dit, met die uitsondering van $13: 52$, op enkele persone dui wie se persoonlikhede uitgestaan het weens hulle kenmerkende "vol wees van die Heilige Gees", naamlik Stefanus $(6: 5 ; 7: 55)$ en Barnabas (11:24). Dat hierdie eienskap vir buitestaanders uitkenbaar was, is

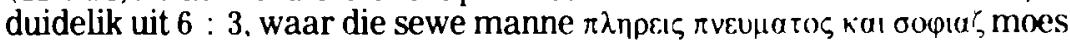
wees.

Wat $\pi \iota \pi \lambda a v a ı$ en $\pi \lambda \eta \rho o u v$ betref, kan dus gesè word dat dit van toepassing gemaak word op mense wat wel die Heilige Gees as gawe van God ontvang het (vgl. studie 4.1.4) maar wat tog op besondere geleenthede of op besondere wyse besondere werkinge van die Heilige Gees ervaar het. Die gawe ( $\delta \omega \rho \varepsilon \alpha)$ van die Heilige Gees wat in $2: 38$ as regstreekse vrug van Pinkster aangedui word, was deurentyd die krag

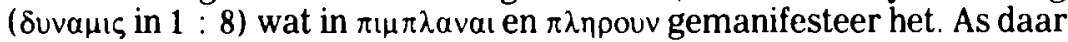
dus onderskei word tussen "vervul wees met": ( $\left.\pi \mu \pi \lambda \alpha^{2} \alpha_{1}\right)$ en "vol wees

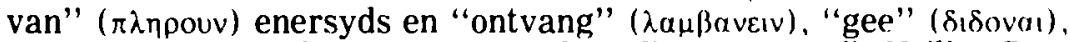

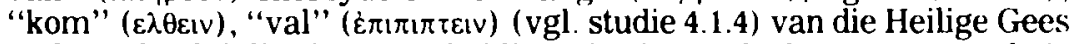
andersyds, dui dit nie op 'n skeiding nie; inteendeel, eersgenoemde is 'n vrug van laasgenoemde, maar laasgenoemde word ook in eersgenoemde bevestig. Juis hierdie cenheid in die werk van die Heilige Gees was die krag in die opbouwerk van die Heilige Gees. Hy het nie net in die massa "gekom" nie maar het ook die individu "gevul" en opgebou deur elke gelowige met sy werk vol te maak.

Daar moet versigtigheid aan die dag gelè word dat nie te veel in $\pi \mu \lambda u v a l$ in $2: 4$ ingelees word as teenstelling met $\lambda \alpha \mu \beta \alpha v \varepsilon$, in $0 . a .2: 38$. nie Grosheide $(1942: 50)$ sien in $\pi u \pi \lambda$ rval (in $2: 4$ ) 'n versterking van die feit dat hulle volkome deur die Heilige Gees beheers is, sovecl en in so 'n mate dat "de gemeente van karakter veranderd", in verband met $7: 55$ (Stefanus) dat "de gemeente is hemelsch geworden" (ibid.). Afgesien daarvan dat $7: 55 \pi \lambda$ npouv gebruik en nie $\pi ı \pi \lambda a v a ı$ nie, is die 
vervulling nie 'n karakterverandering nie maar eerder 'n verryking, 'n verdieping en versterking van die bestaande karakter van die gelowige wat reeds deur sy ontvangs ( $\lambda \alpha \mu \beta \alpha v \varepsilon i v)$ van die Gees van karakter verander het en reeds in al die "hemelse gawes" van Jesus Christus deel.

Die besondere betekenis van $\pi \lambda \eta \rho o u v$, as 'n besondere vervulling van die gelowiges, blyk uit $13: 52$. As hierdie gelowiges deur die apostels se weggaan sonder aardse leiers gelaat word, verval hulle nie in bekommernis nie maar ontstaan daar blydskap! Dit is die vrug van die werk van die Heilige Gees. Die imperfektum ( $\xi \pi \lambda \eta$ pouvio) dui op die voortdurende vervul wees met blydskap, gewerk deur die Heilige Gees (vgl. Oulton, $1954:$ 45).

Versteeg (1976:25) beweer: "Uit het boek Handelingen kunnen we de indruk krijgen, dat de vervulling met de Geest iets is, dat helemaal buiten de gelovige zelf omgaat, doordat het hem overvalt", met verwysing na $2: 4 ; 4: 31$ en andere. Versteeg meen dat Paulus se briewe verduidelik hoe die opvatting van Lukas in Handelinge verstaan moet word, naamlik " . . . dat van een vervulling met de Geest die buiten de gelovige omgaat geen sprake is"(ibid.). Hierdie "indruk" wat Versteeg uit Handelinge aflei, blyk ongeregverdig te wees, enersyds omdat die gelowige wat met die Gees vervul word $(\pi \mu \pi \lambda \alpha v a$ in $2: 4 ; 4: 8 ; 4: 31$ e.a.), iemand is wat reeds die Heilige Gees ontvang het. Andersyds is dit onmoontlik dat 'n vervulling buite die gelowige omgaan, want die Gees vervul juis die gelowige op grond van die belofte van die Vader wat nie buite om die gelowige gaan nie maar sy lewe radikaal bepaal.

Met Green (1975 : 150) word saamgestem dat die "vervul met die Heilige Gees" nie altyd net spreek in vreemde tale as vrug het nie (in reaksie op die "Pentacostals"). Green toon byvoorbeeld uit 4:8 aan dat Petrus met die Heilige Gees vervul was, maar daar was "no tongues, no praise, no never-to-be-repeated experience, but bold preaching" (op cit: $150-151)$, soos ook in $4: 31 ; 9: 17 ; 13: 9$.

Oulton (1954: 42) maak 'n skeiding tussen die werk van die Heilige Gees en Jesus deur te beweer dat Christene in die eerste deel van Handelinge met die Heilige Gees vervul is ( $\pi \lambda \eta \sigma \theta \varepsilon v \tau \varepsilon \varsigma)$, en in die tweede deel is hierdie spesiale werk van die Heilige Gees deur visioene van Christus gegee (bv. $18: 9,10 ; 23: 11 ; 27: 23,24$ ). Afgesien daarvan dat in $19: 2,6$ nog van die ontvang van die Heilige Gees sprake is en visioene van Christus reeds in byvoorbeeld 9:4-6 voorkom, word hierdeur 'n skeiding gemaak wat nie so skerp gemaak behoort te word nie. Die besondere leiding wat die apostel van die Heilige Gees ontvang (bv. $16: 6 ; 20: 23 ; 21: 4,11$, getuig daarvan dat die Heilige Gees steeds aan mense besondere krag en insig gegee het. Dit word wel nie met die woord $\pi \iota \pi \lambda \alpha v_{a}$ aangedui nie, maar die saak is duidelik dat die Heilige Gees steeds op 'n besondere wyse gewerk het. Hierdie bewerking van Oulton lê moontlik te veel klem op die eksklusiewe inhoud van $\pi \iota \mu \pi \lambda a v a ı$, maar dit bly 'n belangrike waarieming. Dit mag 'n aanduiding wees dat die besondere vervulling ( $\pi i n \lambda a v a l)$ en uitsnriderlike vol wees $(\pi \lambda \eta \rho o u v)$ van die Heilige Gees hooisaaklik tot die heel begin van die Christelike kerk beperk was. Die feit is dat in Hand 13 die laaste keer gepraat word van "vol van dic Heilige Gees" wees. Het die Heilige Gees 
dan in die beginfase van die kerk die individuele lidmate intensiewer opgebou as later?

Die verband tussen die drie uitdrukkings "doop met", "ontvang van", "vervul met" die Heilige Gees word in $2: 1$ - 4 op 'n uni ske wyse aangedui. Floor (1979: 63) beweer: "Die gelowiges wat in Hand 2 met die Heilige Gees gedoop word, word ook met die Gees vervul (Hand 2: 4). Doop en vervulling gaan hier saam". Hierdie gelowiges wat blykens $2: 1-4$ byeen was, was reeds gelowiges wat in $1: 15 \dot{\alpha} \delta \varepsilon \lambda \varphi 0$ genoem word. Hulle het dus reeds die Heilige Gees in die sin van $\lambda \alpha \mu \beta a v \varepsilon ı$ ontvang. Volgens die belofte van $1: 4,5$ sou hulle wel met die Heilige Gees gedoop word. Dit is 'n sterk moontlikheid dat hierdie groep as 'n buitengewone groep bestempel moet word en dat die belofte van die

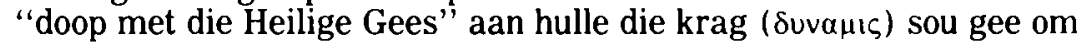
getuies te wees, om te praat (soos dit inderdaad in $2: 4$ gebeur het). Hierin stem dit ooreen met dit wat later in Handelinge as "vervul met die Heilige Gees"' (vgl. $4: 8$ ) bekend staan. Die feit dat dit nie genoem word dat hulle met water gedoop is nie (soos wel in $2: 41 ; 8: 12,13$; $10 ; 48 ; 19: 5$ ), dui ook daarop dat die gebeure in $2: 1-4$ nie op dieselfde lyn lê as die ander waar van "ontvang van die Heilige Gees" sprake is nie. In hulle geval word van $\pi i \mu \pi \lambda a v a$ gepraat, wat dui op die krag wat hulle ontvang het om te praat $(2: 4)$. "Doop en vervulling" gaan dus in wese hier saam, maar dit was 'n hoogs uitsonderlike gebeurtenis wat slegs op hierdie een groep mense en hierdie een geleentheid van toepassing gemaak behoort te word.

Uit bogenoemde gegewens blyk dit dat die vervulling met die Heilige Gees een van die duidelikste manifestasies van die opbouwerk van die Heilige Gees in Handelinge was. Dit het op ' $n$ besondere wyse enkelinge vir uitsonderlike take toegerus $\left(\pi i \mu \pi \lambda\left(v u_{1}\right)\right.$, en ander het blyke gegee dat hulle as persone vol van die Heilige Gees was ( $\pi \lambda \eta \rho \circ u v)$.

\subsection{Die Heilige Gees en die plaaslike gemeentes}

\subsubsection{Enkele dieptesnitte}

\subsubsection{Gemeentevorming as doel van Pinkster}

Dit is duidelik dat die Pinkstergebeure nie 'n doel op homself was nie, maar dat Christus se doel daarmee was om aan die gelowiges krag te gee om getuies te wees $(1: 8)$. Dit gebeur inderdaad in die praat in ander tale $(2: 4-11)$ en die prediking van Petrus $(2: 14$ e.v.) dat hulle getuies was. Maar ook hierdie getuienis was weer nie 'n doel op homself nie. Die doel daarvan was bekering, soos uit $2: 38$ blyk. Maar die bekering was ook nie die eindpunt van die gelowiges se lewe nie. Daarna is hulle in 'n eenheid van die gemeente saamgebind, soos uit $2: 42-47$ blyk. In die geheel van Hand 2 gesien was die bestaan van ' $n$ plaaslike gemeente die ware eindproduk van Pinkster. Hierdie gemeente sou nou die woord verder uitdra om weer ander tot bekering te bring, sodat die gelowiges telkens in 'n gemeentelike lewe sou funksioneer.

Die bestaan van 'n gemeente is die eindpunt van die proses wat Christus deur die Heilige Gees begin. Hierdie uitgangspunt is belangrik vir die regte siening van $2: 42-47$ en vir die inhoud van hierdie hoofstuk. Die uitvloeisel hiervan is dat al die voorafgaande werk tot gemeentevorming lei. En hierdie plaaslike gemeentes moes bly voortbestaan, moes op- 
gebou word om as verdere bolwerk te dien, as instrumente van Jesus Christus deur die Heilige Gees.

Dit is daarom ook ' $n$ gewettigde afleiding om 2 : 42 - 47 as ' $n$ baie belangrike aanduiding van die wesenskenmerke van die lewe in die plaaslike gemeente te sien (vgl. Coetzee, 1967: 47; Cullman, 1962:12; Goppelt, 1980 : 45 47). Omdat hierdie vier wesenskenmerke die afrondende eindpunt van die werk van die Heilige Gees in Hand 2 is, is dit vir hierdie studie van wesenlike belang.

3.4.1.2 Die vier elemente in Hand $2: 42-47$

Die verskillende elemente wat in $2: 42$ genoem word, is:

1. die leer van die apostels;

2. die gemeenskap;

3 . die breking van die brood;

4. die gebede.

Die verband van hierdie vier wesenskenmerke word deur die volgende chiasme (Coetzee, $1983 ; 13$ ) aangetoon:

$2: 42$

SKETS 3

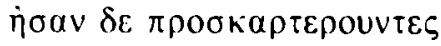

a

$\tau \eta ̣ \delta$

b

Ka! โற Kolv(t)via,

b

a

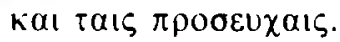

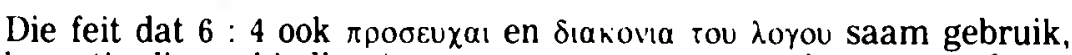
bevestig die verbinding tussen $\delta_{1} \delta \alpha \chi \eta$ en $\pi \rho \circ \sigma \varepsilon u \chi \alpha ı$ in $2: 42$. Volgens hierdie chiasme word die gemeenskap en die breking van die brood bepaal en van die ware inhoud voorsien deur die leer van die apostels en die gebede. Die leer van die apostels, wat as inhoud die evangelie van Jesus gehad het, en die gebede, wat tot Jesus Christus en God gerig was, "omarm" die gemeente se gemeenskap en breking van die brood. Laasgenoemde twee elemente se ware inhoud was dus: Jesus Christus en God. Dit het nie om die gemeente gegaan nie, maar om Jesus Christus en sy voortgesette woorde $\left(\delta_{1} \delta \alpha \chi \eta\right.$ en $\left.\pi \rho \circ \sigma \varepsilon \chi \alpha_{1}\right)$ as basis vir sy voort-

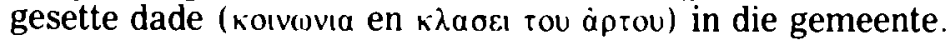

Hierdie vier elemente word in $2: 43-47$ saaklik herhaal en dit is opmerklik dat dieselfde chiastiese konstruksie aanwysbaar is: Vergelyk skets 4 .

Hierdie tweede chiasme in $2: 43$ - 47 kan as 'n verklaring en uitbreiding van die chiasme in $2: 42$ beskou word. Die optrede van die apostels wat die gelowiges saambind (v. 43b, 44a) en die lofprysing aan God (Hy wat die gemeente saamstel - v. 47). "omarm" ook hier die gemeenskap (v. $44 \mathrm{~b}-45$ ) en die breking van die brood as deel van die godsdienstige samekomste (v. 46). 
34 In die Skriflig

$2: 43-47$

43

44

45

46

47
SKETS 4

[Almal was met ontsag vervul, en]

die apostels het baie tekens en wonders gedoen. En die gelowiges

was bymekaar en het alles met mekaar gedeel.

Hulle het hulle grond en besittings verkoop en die geld aan almal uitgedeel volgens elkeen se behoefte.

Hulle het elke dag eendragtig by die tempel bymekaargekom, en van huis tot huis brood gebreek, en hulle kos met blydskap en in eenvoud van hart geniet.

Hulle het God geprys.

[En die hele volk was hulle goedgesind.] En die Here het elke dag die wat gered is by die gemeente gevoeg.

Die feit dat bogenoemde vier elemente van $2: 42$ in die volgende verse saaklik herhaal word, dui daarop dat dit die basiese elemente was wat bly voortbestaan het. Die woorde $\kappa \alpha \theta^{\prime} \dot{\eta} \mu \varepsilon \rho \alpha v$ en $\kappa \alpha \tau^{\prime}$ oi ${ }^{\prime}$ ov in $2: 46$ onderstreep hierdie feit: dit het van dag tot dag en van huis tot huis plaasgevind. Hier is dus sprake van 'n voortgaande, opbouende proses.

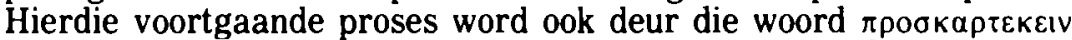
(volhard) beklemtoon - vgl. $1: 14 ; 2: 42 ; 2: 46 ; 6: 4$. Floor $(1964: 63)$ wys daarop dat hierdie volharding wesenlik is aan die opbou van die gemeente, ook met verwysing na $11: 23$ en $14: 22,42$.

Dit is duidelik dat die elemente van $2: 42$ die wesenskenmerke van die eerste gemeentelike lewe aandui as vrug van die Pinkstergebeure en dat dit klaarblyklik voortgeduur het. Hierdie vier elemente is as uitgangspunt geneem om vervolgens te ondersoek hoe en in watter mate dieselffde kenmerke verder in Handelinge ter sprake kom en hoe die Heilige Gees dit tot opbou van die gemeentes bepaal het.

\subsubsection{Die woorde $\pi \alpha \rho \alpha \kappa \alpha \lambda \varepsilon \iota v$ en $\dot{\varepsilon} \pi ı \tau \eta \rho \iota \zeta \varepsilon ı v$}

Die twee woorde $\pi \alpha \rho \alpha \kappa \alpha \lambda \varepsilon ı$ en $\varepsilon \pi$ ' dere aspek van die opbou van die gemeentes.

Agtereenvolgens word die gegewens aangedui hoe die gemeentes opgebou is:

- deur die apostels

- deur die voorgangers

- deur bepaalde nasorg. 


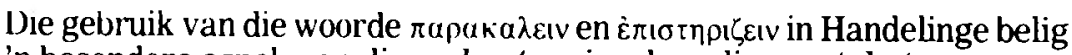
' $n$ besondere aspek van die ondersteuning deur die apostels (vgl. Noordegraaf, $1983: 98-108$ ). Hoe hulle die gelowiges opgebou het, blyk uit $14: 22$ :

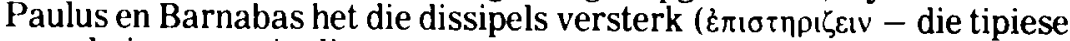
woord vir nasorg in die gemeentes vgl. Grosheide, 1942:469); deur hulle te vermaan om in die geloof te bly. Die gesamentlike gebruik van $\pi \alpha \rho \alpha$ -

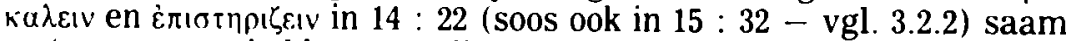
met tas $\psi v x \alpha v$ beklemtoon die innerlike, inwendige opbou van die

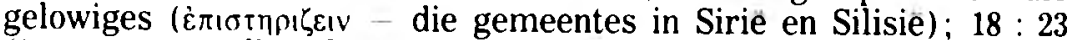

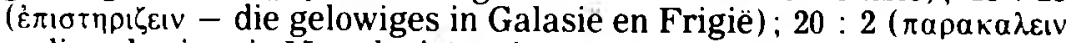
- die gelowiges in Masedonië) en in $20: 12$ ( $\pi \alpha \rho \alpha \kappa \alpha \lambda \varepsilon ı v$ - die gelowiges in Troas). Dit getuig van 'n doelgerigte ondersteuning van die gemeentes.

Die aspek van bemoediging word in $16: 40$ ook deur $\pi \alpha \rho \alpha \kappa \alpha \lambda \varepsilon i v$ aangedui (Noordegraaf, $1983: 103$ ). Hulle het die broeders aan huis van Lidia gesien, hulle bemoedig en toe weggegaan. Ook hier is sprake van versterkende opbouwerk in die gemeente. Die apostels was op die punt om weg te gaan nadat hulle uit die gevangenis in Filippi losgelaat is. Nou bemoedig en versterk hulle die gemeente. Hierdie selfde gedagte kom ook in $20: 1$ voor, waar Paulus die dissipels in Efese, na die oproer, moed inpraat.

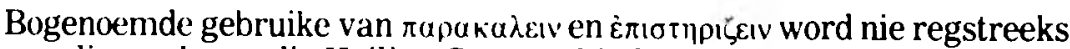
aan die werk van die Heilige Gees verbind nie. In 9 : 31 word "die vertroosting van die Heilige Gees" wel met $i n \pi \alpha \rho \alpha \kappa \alpha \lambda \eta \sigma \varepsilon ı$ tou à $\mu \alpha \tau o \zeta$ aangedui. 'n Verband tussen die werk van die Heilige Gees en $\pi \alpha \rho \alpha \alpha \lambda \lambda_{c i v}$ is ook in $15: 31$ aan te dui, want die inhoud van die brief wat die gemeente in Antiogie bemoedig het. was onder andere dat "die Heilige Gees en ons" ( $15: 28)$ besluit het om geen onnodige las op hulle te lê nie.

\subsection{Deur die voorgangers}

Volgens $11: 23$ het Barnabas, gestuur deur die gemeente van Jerusalem, die gelowiges in Antiogie (in Siriê), bemoedig om aan die Here getrou te bly. In $11: 23$ staan $\pi \alpha \rho \varepsilon \kappa \alpha \lambda \varepsilon$ in die imperfektum 'n werkwoordvorm wat ' $n$ voortdurende aktiwiteit aandui. Hier is sprake van 'n proses van opbouwerk in die gemeente. Judas en Silas het volgens $15: 32$ ook die

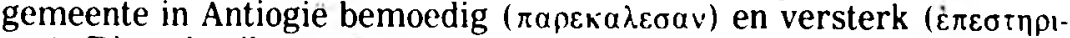

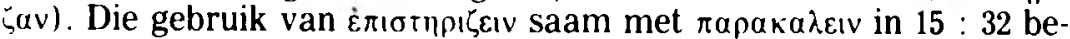
klemtoon die doelgerigte opbouwerk in die gemeente van Antiogiè. Die

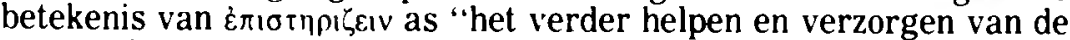
pas gestichte gemeenten" (Grosheide. 1942: 469) onderstreep die besondere opbouende werk van Judas en Silas

Die gemeente van Antiogie is dus op ' $n$ besondere wyse bemoedig om sy belangrike rol in die kerk van Christus te vervul. Blykens $11: 23$ was die genade $(\chi \alpha \rho) \zeta)$ van God in hierdie gemeente sigbaar. Hierdie genade van God sou geblyk het uit die groot aantal ( $\pi \circ \lambda \cup \varsigma \tau \varepsilon \alpha \rho t \theta \mu o \zeta$ in v. 21) maar ook uit die kwaliteit van die gemeente se geloofslewe. Hierdie $\chi a \rho 15$ hou dus die werk van die Heilige Gees in wat in Antiogie sigbaar was. Daarom word hulle aangemoedig om hierin te volhard.

'n Belangrike aspek van hierdie bemoediging was die wyse waarop die 
Skrifte (vgl. studie 2.4.3) aan die gelowiges verklaar is en hoe die vervulling van die profesiee aangedui is.

\subsection{Deur bepaalde nasorg}

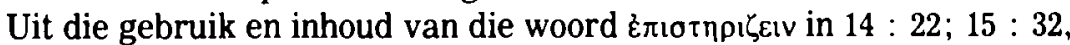
$41 ; 18: 23$ blyk dit dat daar 'n bepaalde nasorg in die gemeentes was juis om hulle in hulle omstandighede by te staan en om die kontinuiteit van die gemeente te waarborg. Uit $14: 22$ is dit duidelik dat die versterking behels het om hulle te vermaan om in die geloof te bly, ten spyte van verdrukkinge. Die woord $\pi \alpha \rho \alpha \kappa \alpha \lambda \varepsilon เ v$ word in hierdie verband gebruik in sy betekenis van vermaning (om in die geloof te bly) en vertroosting (om verdrukkinge te verdra). Die werk van die Heilige Gees was noodsaaklik om as die Ware Nasorger hierdie gemeente hierin by te staan en verder op te bou.

\subsection{Die Heilige Gees en die wêreldwye kerk}

\subsubsection{Enkele dieptesnitte}

\subsubsection{Die groei van die gemeentes wêreldwyd}

Reeds uit Hand 2 is dit duidelik dat, hoewel in $2: 5$ - 11 'n aanvanklike flits van die wêreldwye betekenis van die kerk gegee word, die res van Hand 2 oor die bestaan van die gemeente in Jerusalem handel; trouens, Hand 2 - 7 handel net oor Jerusalem.

Waarom het die apostels nie dadelik aan die werk gespring om die opdrag in $1: 8$ uit te voer nie? Die antwoord is dat die kerk in Jerusalem eers sterk opgebou moes word (vgl. studie 2.5.2). In hierdie opbou van die gemeente in Jerusalem het die Heilige Gees (vgl. studie 5.2; 5.3.1) 'n leidende funksie vervul. Die Gees bou eers die plaaslike gemeente op, rus hulle toe om die Woord uit te dra en is dan intensief betrokke om die uitbreidende kerk ook toe te rus. In hierdie sin moet die terme intern en ekstern nie teenoor mekaar gestel word nie, want die eksterne, wêreldwye groei en bestaan van die gemeentes het ook interne leiding en opbouwerk deur die Heilige Gees geverg. Daarom staan uitbreiding van die kerk en opbou in die kerk nie teenoor mekaar nie. Vir die voortskrydende uitbreidingswerk van die kerk was daar algaande opbouwerk nodig.

Hierdie feite blyk uit die gegewens in Handelinge, byvoorbeeld in die woord aú aveıv, wat in $6: 7 ; 12: 24 ; 19: 20$ vir die kerk se groei gebruik word. Die hoofklem val in $6: 7$ op die eksterne uitbreiding van die Woord (Grosheide, $1942: 201$; Marshall, 1980 : 127; Neil, 1973 : 105), maar die verband van $6: 1-6$ toon tog aan dat dit berus het op die feit dat die gemeente se interne situasie $(6: 1,2)$ opgelos is (Noordegraaf, $1983: 128)$. Hierdie sinspeling op die interne groei word versterk deur die gebruik van

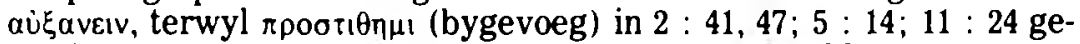
bruik word. Die woord aủ $\alpha$ veıv wil dus iets meer sê as bloot 'n toename in getalle, hoewel Noordegraaf $(1983: 51,54,49,70,71)$ aantoon dat ook in die geval van $\pi$ poor $\theta \eta \mu$ " "de toevoeging in kwantitatieve zin ... niet los (staat) van de innerlijke groei van de gemeente" (bl. 70). Dit dui op die algehele groeiproses wat die gemeente ondergaan het. Die opbouwerk onder die leiding en krag van die Heilige Gees het die geloof in

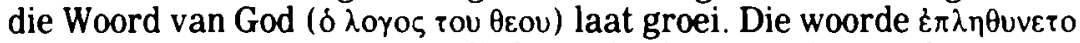
$\delta \dot{\alpha} \rho, \theta \mu \circ \zeta$ in $6: 7$ onderstreep die kwantitatiewe groei, naamlik dat die 
gemeente ook in getal vermeerder het.

Ook in $12: 24$ is daar sprake dat "die Woord van God gegroei en (die gelowiges in getal) toegeneem het". In $12: 24$ word die gemeentes buite Jerusalem (vgl. Judea, Galilea, Samaria in $9: 31$; Sesarea in $10: 44$ 48; $12: 19$; Antiogie in $11: 26$ ) ook by die "groei en toename" ingesluit. Die twee imperfektums ( $\eta \dot{\xi} \xi \alpha v \varepsilon v$ en $\dot{\varepsilon} \pi \lambda \eta \theta v v \varepsilon \tau o$ ) stem ooreen met die wat in $6: 7$ van Jerusalem gegeld het, en dui op die voortgaande groei en toename. Ook hier dui aủ $\alpha_{\alpha \varepsilon \iota v}$ meer op die interne groeiproses, die gemeente wat al sterker word en daarmee saam ook uitbrei ( $\left.\pi \rho 0 \sigma \tau \theta \eta_{\mu 1}\right)$.

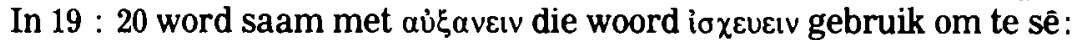
die Woord van die Here het gegroei en sterk geword. Die werklike

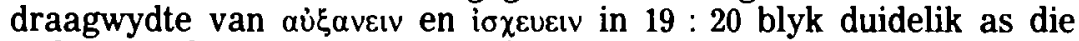
gedagtestruktuur van $19: 10-20$ in ag geneem word. In hierdie stadium in die geskiedenis van die kerk word die wêreldwye trefkrag van die evangelie van Jesus Christus in $19: 10$ - 20 met hierdie tipiese uurglaskomposisie beklemtoon. Vergelyk skets 5 .

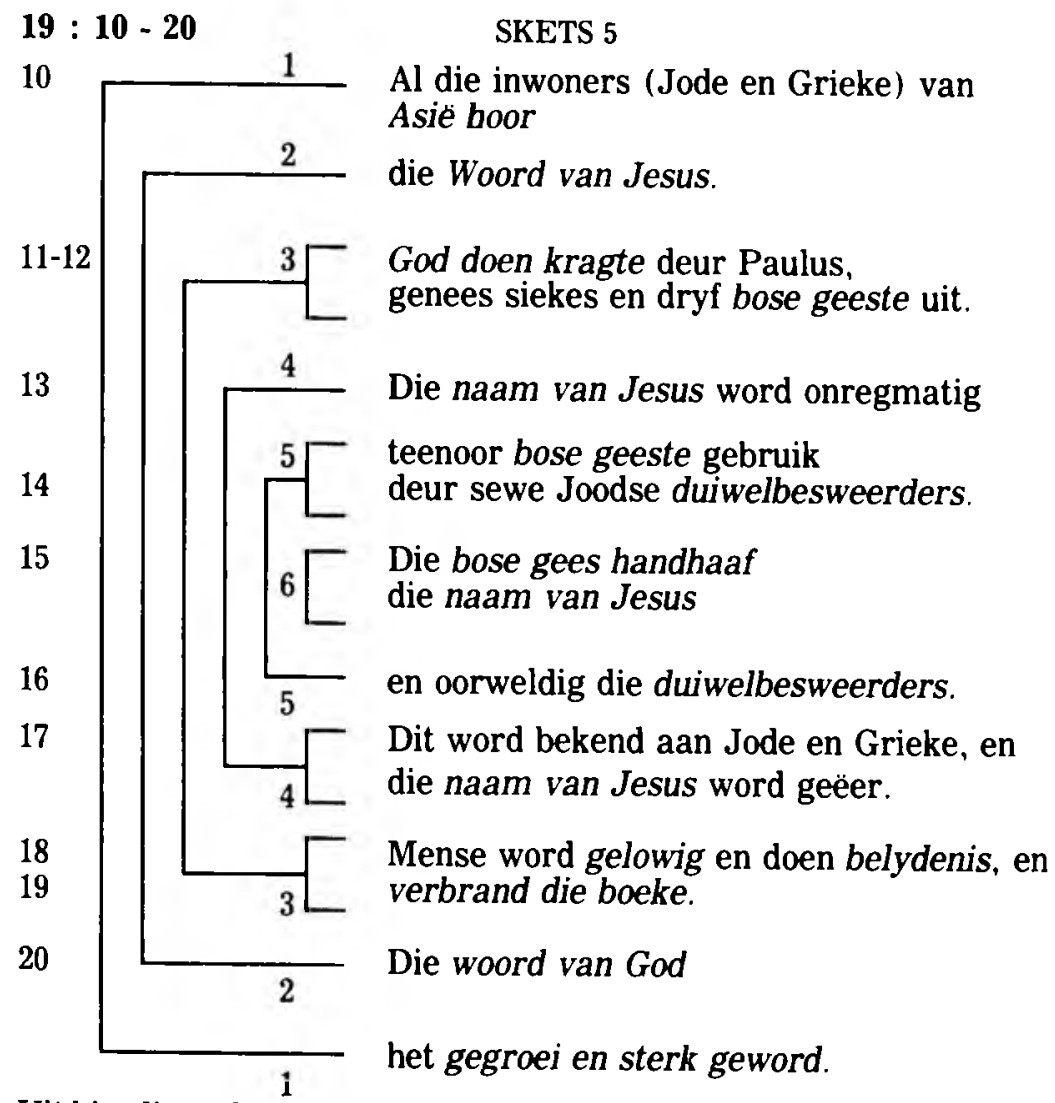

Uit hierdie gedagtestruktuur blyk die feit dat dit hier inderdaad om die vestiging en uitbreiding van die Woord van God/Jesus (2) oor die hele Asië gaan, soos ook in Efese (1). Dit gaan hier kennelik oor 'n konfrontasie tussen kragte (3): Paulus, wat die krag van God in die besondere 
kragte openbaar (v. 11, 12), sodat die mense in Jesus sou glo (v. 18). Hierdie kragte van Paulus word beklemtoon as die bose magte in die middel van hierdie uurglaskomposisie $(5,6)$ as ' $t$ ware self die stryd uitstry, sodat aangetoon word dat die Naam van Jesus geeer moet word (4). So word mense (3) gelowig (v. 18) deur die kragte wat God deur Paulus doen (v. 11, 12), maar dit gaan in wese om die Naam van Jesus $(4,6)$. Jesus se Naam $(4,6)$ is die ware $\mathrm{krag}$ wat die Woord van die Here (2) in Asie (v. 10) en Efese (v. 17) laat groei en sterk word (1).

Die feit dat hier ' $n$ botsing van kragte is $(3,5,6)$, verklaar die gebruik

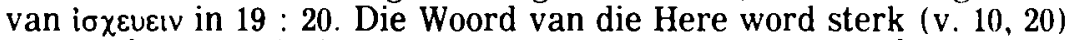
teenoor bose magte (vgl. Noordegraaf, 1983: 141 - 142) wat sterk wou wees

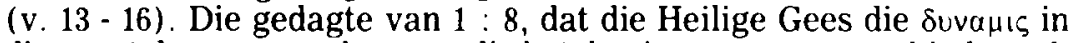
die apostels sou wees, kan aan die betekenis van io x.veıv verbind word. Die apostel Paulus het in hierdie "botsing van kragte" sy krag van die Heilige Gees ontvang. In hierdie sin was die Heilige Gees onregstreeks betrokke by die "sterk word" van die Woord van die Here in Asië (v. 10) soos ook in Efese (v. 17)

Volgens hierdie interpretasie van die gedagtestruktuur van $19: 10-20$ is daar ' $n$ verband aan te toon tussen die plaaslike gemeente (Efese) en die wêreldwye kerk (Asië) en kan die betrokkenheid van die Heilige Gees in hierdie voortgang van die Here se Woord en die evangelie van Jesus aangetoon word. Dit was dus nie net 'n oppervlakkige, kwantitatiewe groei in getalle nie maar 'n intensiewe, kwalitatiewe groei in krag. Dit was 'n groot groeiproses in die kerk wat onder leiding van die Heilige Gees geskied het.

Uit die voorgaande blyk dit dat daar 'n duidelik aanwysbare band tussen die plaaslike gemeente en die wêreldwye kerk bestaan het.

Op hierdie wyse het die Heilige Gees die plaaslike gemeente en daarom ook die kerk wêreldwyd onder sy leiding en sorg gehad. Die ganse kerk is deur die Heilige Gees opgebou - hoe klein cuie begin in die meeste gevalle ook al was. Soms het hulle net in 'n bovertrek byeengekom (Troas in $20: 7$ ) ; soms was dit by 'n bidplek buite die stad (Filippi in $16: 16$ ), soms in 'n saal (Efese in $19: 9$ ). Orals was die Heilige Gees plaaslik besig om die kerk wêreldwyd op te bou.

\subsubsection{Die gemeentes beraadslaag saam volgens Hand 15}

Die wyse waarop blykens Hand 15 saam beraadslaag is, is 'n sprekende voorbeeld van hoe die eenheid in die kerk gerealiseer is. Die persone uit Judea het die eenheid versteur $(15: 1)$ met hulle eis dat die gelowiges wat nie besny is nie, ook besny moes word en die wet moes onderhou (v. 24). Daar moes dadelik aan hierdie eenheid in die kerk gewerk word, want oor hierdie saak is skerp verskil (v. 2). Barnabas en Paulus $(11: 26)$ het met die evangelie gekom (vgl. die "deur van die geloof" in $14: 27)$; die manne uit Judea het die Wet van Moses probeer afdwing $(15: 1,5)$. Hierdie verskil het binne-in Antiogie bestaan, en nie in Jerusalem nie - daarom moes die apostels en die ouderlinge van Jerusalem wesenlik arbiters wees (vgl. v. $22-29$ ) in die oplossing van hierdie vraag (v. 2).

Maar dit was ook belangrik dat die hele kerk hieroor 'n eenheid van standpunt en optrede moes hé, want in Jerusalem (Judea) is Jode- 
christene nog besny, en in Antiogie is dit nie gedoen nie (Grosheide. 1948 : 19). Die gelowiges in Antiogie het sonder meer met Jerusalem in verbinding gekom, omdat die eenheid tussen die gelowiges van Antiogie en Jerusalem reeds bestaan het. "Thus the moment a divisive question arose, that question was regarded as one that the entire church must decide" (Lenski, 1961 : 595). Die byeenkoms van $15: 4$ e.v. het dus nie die eenheid geskep nie maar was 'n bewys van die eenheid wat reeds geskep is. Hierdie byeenkoms sou wel hierdie eenheid verdiep en dit onder die leiding van die Heilige Gees verder uitbou.

In die beraadslagings het die Heilige Gees en sy werk daadwerklik op die voorgrond getree. Petrus beroep hom in $15: 8$ weer eens op die feit

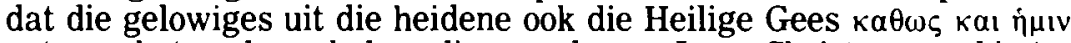
ontvang het en dus ook deur die genade van Jesus Christus gered is ( $\mathrm{v}$. 11). Die gelykheid tussen die gelowiges in die kerk was vir Petrus so kardinaal dat hy in v. 11 die volgorde van v. 8 omruil: in v. 8 sê hy dat die gelowiges uit die heidene "net soos ons" die Heilige Gees ontvang het; in v. 11 stel hy dat die gelowiges uit die Jode "net soos hulle" gered word (vgl. Coetzee, $1965: 275$ ). Hierdie eenheid tussen die gelowiges was steeds 'n belangrike basis vir die eenheid tussen die gemeentes. Want met dit as uitgangspunt het Petrus sy betoog gevoer dat op die nek van die dissipels ( $\tau \omega v \mu \alpha \theta \eta \tau \omega v$ ) nie 'n juk gelê moes word "wat ons vaders en ook ons nie in staat was om te dra nie" (v. 10). Die hele betoog veronderstel die eenheid tussen die gelowiges.

In Jakobus se bydrae in $15: 13-21$ is dit duidelik dat hy die gedeelte uit Amos $9: 11$ - 12 hier toepas met die woorde in $15: 19: \delta ı$ \& $\gamma \omega \kappa \rho ı v \omega$. Hierdie beoordeling en toepassing van Jakobus het onder die leiding van die Heilige Gees gestaan, soos later in v. 28 bely is. Die Heilige Gees het die byeenkoms deur die oordeelsvermoe van almal teenwoordig tot 'n besluit gelei (v. 22).

Die aanhef van die brief in $15: 23$ is ' $n$ illustrasie van die eenheid in die kerk. Die saak het nie net die broeders in Antiogie geraak nie, maar ook die in Sirië en Silisië. Laasgenoemde twee plekke word waarskynlik genoem omdat Paulus en Barnabas op hulle tog van Antiogië na Jerusalem ook daar van die bekering van die heidene vertel het (v. 3). Anders kan dit nie verklaar word waarom die brief nie in sy aanhef ook gerig is aan die gemeentes in Ikonium, Listra en Derbe (14:20 - 21) nie, waar daar toe ook reeds gemeentes met ouderlinge $(14: 23)$ was. Die besluit word wel later deur Paulus aan die gemeentes bekend gemaak $(16: 1$, 4) sodat die gemeentes in die geloof versterk is (16:5). Dit was dus ook vir hulle ' $\mathrm{n}$ belangrike antwoord. Maar hulle was nòg teenwoordig of verteenwoordig in Jerusalem nòg in die brief se aanhef aangespreek. Dit gaan dus in Hand 15 klaarblyklik nie om die skep van 'n strukturele kerkverband nie maar wel oor die eenheid van die gelowiges in hulle band aan Jesus Christus onder leiding van die Heilige Gees.

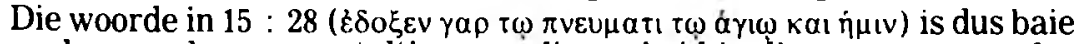
veelseggend as vergestalting van die eenheid in die gemeentes onder leiding van die Heilige Gees. Die Heilige Gees het die gelowiges hier opgebou en versterk om tot hierdie besluit te kom. So het Hy die eenheid in die kerk gebou en was Hy die basis vir die belewing van dit wat die gemeentes gemeenskaplik in Jesus Christus en in God se Woord gehad het. 
In die lig van bostaande beredenering kan die byeenkoms van Hand 15 nie as "die eerste sinode" bestempel word nie (vgl. Grosheide, 1948: 69) asof die "sinode" se besluit die saak opgelos het, die "sinode" "deputate" gestuur het en dus vrede tussen die gelowiges uit die heidendom en die "sinode" gekom het. Dit is genoem dat die apostels en ouderlinge in Jerusalem grotendeels arbiters was, dat slegs twee van die vyf destyds bestaande gemeentes teenwoordig was en (in studie 5.4.2) dat Antiogië nie noodwendig ouderlinge afgevaardig het nie. Die klem moet nie op 'n kerklike struktuur val nie maar op 'n samekoms van gelowiges van twee gemeentes wat saam, onder leiding van die Heilige Gees en in die lig van God se woord, 'n bepaalde twispunt opgeklaar het (v. 1,2).

Die gelowiges uit die heidene het, blykens $15: 31$, hierdie besluit as 'n bemoediging ( $\pi \alpha \rho \alpha \alpha \lambda \varepsilon \mathrm{k}$ ) ervaar. Dit was belewing van ware eenheid tussen die gelowiges. Dit was 'n eenheid waarin saamgestem is oor die hantering en toepassing van die Skrif, waartoe die Heilige Gees die gelowiges gelei het.

Die byeenkoms wat in Hand 15 meegedeel word, was dus 'n sprekende voorbeeld van die bestaande eenheid in die kerk waarop verder voortgebou kon word. Die werk van die Heilige Gees het in hierdie opbou van die kerk 'n grondliggende funksie vervul.

\section{SLOTSOM}

'n Kernagtige samevatting van al die gegewens in Handelinge oor die werk van die Heilige Gees in die opbou van die kerk volgens Handelinge, word soos volg geformuleer:

4.1 Jesus Christus werk deur die Heilige Gees en bou die kerk op die fondament van die Skrif (Skrifte en evangelie) met die drie-enige God as die fokuspunt van die opbou van die kerk.

4.2 Jesus Christus werk deur die Heilige Gees en bepaal die invididuele gelowige se lewe radikaal en omvattend as die wentelpunt van die opbou van die kerk.

4.3 Jesus Christus werk deur die Heilige Gees en bou die gemeentes op tot 'n daadkragtige en ordelike bestaan as die saambindingspunt van die opbou van die kerk.

\section{TERREINE VIR VERDERE ONDERSOEK}

Die inhoud van hierdie studie kan as basis dien vir verdere studies op die volgende gebiede:

5.1 'n Vergelyking tussen die gegewens in Handelinge en veral die briewe van Paulus oor die werk van die Heilige Gees in die opbou van die kerk kan getref word.

5.2 'n Vergelykende studie van die verhouding tussen die opbou en uitbou (uitbreiding) van die kerk in Handelinge kan gemaak word. Die implikasies wat die werk van die Heilige Gees vir die opbou en uitbou van die kerk gehad het, kan ook aangetoon word.

5.3 Die diakoniologiese vakke kan hierdie studie oor Handelinge as vertrekpunt neem en die lyne deurtrek na die betekenis van die werk van die Heilige Gees in die opbou van die moderne gemeente. 
5.4 Die sendingwetenskap kan 'n studie maak van die mate waarin die werk op die sendingveld die opbou van die kerk ten doel behoort te hê (stigtelike werk), en die verhouding hiervan tot die uitbreiding van die evangelie (stigtende werk) $\mathrm{kan}$ in die lig van hierdie studie oor Handelinge verder ondersoek word.

\section{AANGEHAALDE WERKE}

Coetzee, J. C. 1965. Volk en Godsvolk in die Nuwe Testament. Potchefstroom: Pro Rege. Coetzee, J. C. 1967. Enkele Skrifgegewens oor die diakenamp - Handelinge 6 en die diakensamp. In die Skriflig, 1(4) : 44 - 53.

Coetzee, J. C. 1983. Gedagtestruktuurontleding en basiese struktuurpatrone (Illustrasiemateriaal vanuit die Nuwe Testament). Potchefstroom: PU vir CHO. (Diktaat.)

Conzelmann, H. 1978. Geschichte des Urchristentums. (In Friedrich, G., red. Grundrisse zum Neuen Testament. Das Neue Testament Deutsch: Erganzungsreihe, dl. 5. Gottingen: Vandenhoeck \& Ruprecht).

Cullman, O. 1962. Early Christian Worship. London: SCM

Davies, J. G. 1965. The early Christian church. London: Weidenfeld and Nicolson Floor, L. 1964. In dieselfde spore, 'n ondersoek na die struktuur van die sendingwerk. Potchefstroom: Evangelis.

Floor, L. 1976. Die Presbiter by Lukas en Paulus. In die Skriflig, 10(37) : 22 - 33. Floor, L. 1979. Hy wat met die Heilige Gees doop. Pretoria: NG Kerk

Gerritsen, J. M. 1953. Het apostolische ambt. Amsterdam.

Goppelt, L. 1980. Apostolic and post-apostolic times. Gottingen: Vandenhoeck \& Ruprecht.

Green, M. 1975. I believe in the Holy Spirit. London: Hodder and Stoughton.

Grosheide, F. W. 1942. De Handelingen der Apostelen, dl. 1. (In Kommentaar op het Nieuwe Testament Amsterdam: Van Bottenburg).

Grosheide, F. W. 1948. De Handelingen der Apostelen, dl. 2. (In Kommentaar op het Nieuwe Testament. Amsterdam: Van Bottenburg).

Haenchen, E. 1971. The Acts of the apostles. A Commentary. Oxford: Blackwell.

Koole. J. L. 1949. Liturgie en ambt in de apostolische kerk. Kampen: Kok.

Kruger, M. A. 1981. Die Heilige Gees wat heilig maak. Pretoria: Die Skrywer.

Lekkerkerker, A. F. N. 1971. Oorsprong en functie van het ambt. 's-Gravenhage: Boekencentrum.

Lenski, R. C. H. 1961. The interpretation of the Acts of the Apostles. Minneapolis: Augsburg.

Lenski, R. C. H. 1961b. The interpretation of St. Luke's gospel. Minneapolis: Augsburg.

Marshall, I. H. 1980. The Acts of the Apostles. An introduction and commentary. (In Tyndale New Testament commentaries. Leicester: Inter-Varsity).

Neil. W. 1973. The Acts of the Apostles. (In New Century Bible. London: Oliphants). Noordegraaf, A. 1984. Creature Verbi. De groei van de gemeente volgens de Handelingen der Apostelen. 's-Gravenhage: Boekencentrum.

Oulton. J. E. L. 1954. Holy communion and Holy Spirit. London: SPCK.

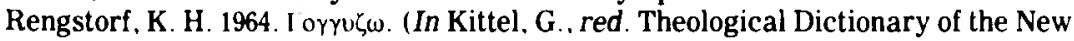
Testament, dl. 1. Grand Rapids: Eerdmans. ss bl. 728 - 737)

Roberts, J. H. 1963 Die opbou van die kerk volgens die Efese-brief. Groningen: VRB.

Sillevis Smitt. P. A. E. 1910. De organisatie van de Christelijke kerk in den apostolischen tijd. Rotterdam: De Vries.

Tolbert, M. O. 1974. Contemporary issues in the book of Acts. Review and Expositor $71(4): 521-531$.

Van Wyk. J. H. 1982. Diakonia en koinonia. In die Skriflig, 16(64) : 46 - 54.

Venter, A. G. S. 1980. Die gesag van die apostoliese prediking volgens die redevoeringe in Handelinge. Potchefstroom. (Verhandeling (Th.M) - PU vir CHO).

Versteeg. J. P. 1976. De Geest en de gelovige. Kampen: Kok 